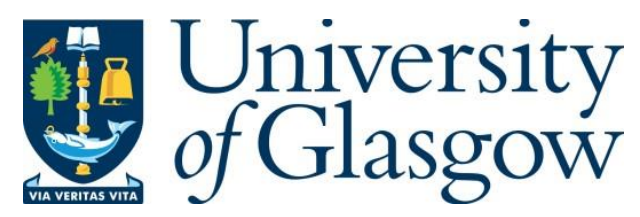

Veenman, D. and Verwijmeren, P. (2021) The earnings expectations game and the dispersion anomaly. Management Science, (doi: 10.1287/mnsc.2021.3983).

There may be differences between this version and the published version. You are advised to consult the publisher's version if you wish to cite from it.

http://eprints.gla.ac.uk/227834/

Deposited on: 8 January 2021

Enlighten - Research publications by members of the University of Glasgow http://eprints.gla.ac.uk 


\title{
The Earnings Expectations Game and the Dispersion Anomaly*
}

\author{
David Veenman \\ University of Amsterdam \\ dveenman@uva.nl \\ Patrick Verwijmeren \\ Erasmus University Rotterdam and University of Melbourne \\ verwijmeren@ese.eur.nl
}

December 2020

\begin{abstract}
This study examines the role of differences in firms' propensity to meet earnings expectations in explaining why firms with high analyst forecast dispersion experience relatively low future stock returns. We first demonstrate that the negative relation between dispersion and returns is concentrated around earnings announcements. Next, we show that this relation disappears when we control for ex-ante measures of firms' propensity to meet earnings expectations and that the component of dispersion explained by these measures drives the return predictability of dispersion. We further demonstrate that firms with low analyst dispersion are substantially more likely to achieve positive earnings surprises, and provide new evidence consistent with both expectations management and strategic forecast pessimism explaining this result. Overall, we conclude that investor mispricing of firms' participation in the earnings expectations game provides a viable explanation for the dispersion anomaly.
\end{abstract}

Keywords: Earnings announcements, sell-side analysts, forecast bias, expectations management, mispricing, forecast dispersion, earnings surprises.

JEL Classifications: D80, G12, G14, G24, M41.

*Parts of this paper were previously part of an early version of the study "Do Investors Fully Unravel Persistent Pessimism in Analysts' Earnings Forecasts?" The Accounting Review (2018) 93(3): 349-377. We thank the Associate Editor and referee, as well as Karthik Balakrishnan, Sjoerd van Bekkum, Henk Berkman, Sanjay Bissessur, Howard Chan, Igor Goncharov, Thomas Keusch, Felix Lamp, Christian Laux, Melissa Lin, Mike Mao, Dong Jun Oh, Peter Pope, Bill Rees, Tjomme Rusticus, Sandra Schafhautle, seminar participants at the University of Bristol, IE Business School Madrid, WU University Vienna, Cass Business School, London Business School, and the University of Florida, as well as participants at the Dutch Accounting Research Conference (DARC) at Maastricht University and the EFMA annual meeting at Nyenrode for helpful comments. 


\section{Introduction}

Firms with high dispersion in analysts' earnings forecasts are associated with significantly lower future stock returns than firms with low dispersion (Diether et al. [2002]). The negative relation between analyst dispersion and returns is puzzling because high-dispersion firms are arguably risky, but they experience relatively low returns.

Interpreting forecast dispersion as a proxy for differences of opinion, Diether et al. [2002] conclude that their result is consistent with Miller [1977]. Specifically, Miller [1977] conjectures that when investors have differences of opinion about the value of a firm, short-sale constraints keep the relatively pessimistic investors from trading the stock. The overpricing induced by this effect increases in differences of opinion and leads to lower stock returns when the overpricing is subsequently corrected. ${ }^{1}$ However, several studies debate whether mispricing explains the dispersion anomaly. Most notably, Johnson [2004] provides a riskbased explanation and argues that dispersion captures idiosyncratic information risk that increases the option value of the firm. He predicts and finds that for a levered firm, higher levels of idiosyncratic asset risk reduce expected returns. ${ }^{2}$

In this paper, we propose that firms' incentives to meet analysts' quarterly earnings expectations provide an alternative explanation for the dispersion anomaly. These incentives arise from the costs that firm managers bear when reporting earnings that miss consensus analyst expectations (e.g., Graham et al. [2005]). To increase the likelihood that earnings meet expectations, firms can manage the information set available to analysts and steer their expectations downwards to beatable levels (Bartov et al. [2002]; Matsumoto [2002]; Hutton [2005]; Cotter et al. [2006]). Analysts, in turn, have incentives to follow these cues from

\footnotetext{
${ }^{1}$ The results from Avramov et al. [2009] are also consistent with mispricing, as they find that forecast dispersion is correlated with financial distress and that the return predictability of dispersion is driven by the low future returns associated with weak credit ratings. Sadka and Scherbina [2007] further find that high dispersion coincides with high trading costs and that less liquid stocks are more overpriced.

${ }^{2}$ See also Barinov [2013]. Doukas et al. [2006] and Barron et al. [2009] separate dispersion into components related to differences of opinion and uncertainty. They find that differences of opinion are positively related to future returns, while the uncertainty component of dispersion is negatively related to future returns, which they interpret as being consistent with Johnson [2004].
} 
management (Feng and McVay [2010]; Ciconte et al. [2014]) or to "lowball" their forecasts to increase access to management (Ke and Yu [2006]; Hilary and Hsu [2013]). This strategic behavior of both analysts and managers, which we label the earnings expectations game, induces a predictable pessimistic bias in analysts' forecasts and causes the majority of firms to meet or beat these biased expectations each quarter.

Our proposed mechanism for the dispersion anomaly rests on two pillars. First, we argue that the earnings expectations game induces a negative relation between analyst dispersion and firms' propensity to meet earnings expectations. As explained in Section 2, expectations management in the form of earnings guidance is expected to reduce dispersion in analysts' forecasts (e.g., Bowen et al. [2002]; Clement et al. [2003]; Irani and Karamanou [2003]). Moreover, the repeated nature of the earnings expectations game decreases dispersion because it increases the precision of analysts' information (e.g., Barron et al. [1998]; Ke and $\mathrm{Yu}$ [2006]) and it reduces the magnitude and volatility of firms' earnings surprises over time. Therefore, we argue that portfolio sorts of firms by analyst dispersion, as in Diether et al. [2002], also produce sorts on the ex-ante likelihood that firms report earnings that meet analyst expectations.

The second pillar relates to the pricing implications of the earnings expectations game. For the relation between dispersion and firms' earnings surprises to explain the dispersion anomaly, investors should not fully unravel the relation between dispersion and firms' propensity to meet analyst expectations. Recent work by Veenman and Verwijmeren [2018] and Johnson et al. [2020] provides evidence that supports this notion. These studies find that ex-ante measures of analyst forecast pessimism and firms' expectations management incentives, respectively, are strongly related to subsequent earnings announcement returns. Their results are consistent with the earnings expectations game inducing predictable errors in investors' earnings expectations.

For a large sample covering the period 1993 to 2019 and using dispersion variables based on annual and quarterly earnings forecasts, we first replicate the result that high-dispersion 
firms have significantly lower future stock returns than low-dispersion firms. We demonstrate that this effect is concentrated in (expected) earnings announcement months and around the earnings announcement date. In fact, we find that the negative relation between dispersion and returns is no longer visible when we exclude the earnings announcement window from the monthly returns. In a multiple regression framework explaining the returns in expected earnings announcement months, the return differences based on forecast dispersion are robust to controlling for other predictive firm characteristics and are not explained by short-sale constraints in our sample.

Next, we show that the relation between dispersion and returns weakens materially when we control for the expectations management incentives (EMI) and forecast pessimism (PESS) measures from Johnson et al. [2020] and Veenman and Verwijmeren [2018]. For instance, the average return spreads between firms with low and high annual forecast dispersion drop from 61 to 27 basis points after including these variables in the regression. To further understand this result, we use a two-stage approach in which the first stage consists of decomposing dispersion into components that are explained versus unexplained by the EMI and PESS measures. The first-stage results indicate that dispersion is strongly negatively related to the EMI and PESS measures. In the second stage, we regress returns on these orthogonal components and find that the fitted values of dispersion drive the negative relation between dispersion and returns. For the residual component of dispersion, we do not find a significant relation with returns. These results are consistent with the earnings expectations game playing an important role in explaining the dispersion anomaly.

When we combine these results into a trading strategy, we uncover statistically and economically highly significant differences in portfolio returns in expected earnings announcement months. Specifically, a portfolio of firms in the lowest quintile of fitted analyst dispersion (i.e., dispersion explained by the EMI and PESS measures) produces monthly riskadjusted returns that are 94-108 basis points higher than a portfolio of firms in the highest quintile of fitted dispersion. These differences in risk-adjusted portfolio returns are measured 
after controlling for both standard risk-factor exposures and an earnings announcement risk factor (Chang et al. [2017]; Johnson et al. [2020]).

We also provide more evidence on the mechanism explaining the link between dispersion and firms' propensity to meet expectations. Conditional on other variables, firms in the lowest decile of dispersion are approximately 22 percentage points more likely to meet expectations than firms in the highest decile. Consistent with the earnings expectations game providing an explanation for this link, we find that earnings guidance significantly reduces dispersion within the firm-quarter (while increasing the probability of meeting expectations). We further find that firms more likely engaged in the earnings expectations game display less volatile earnings surprises, which suggests that low dispersion is consistent with earnings being more predictable for these firms. Moreover, these firms' analysts issue forecasts closer to the prevailing consensus, are more likely to lowball forecasts by one or two cents, and are more likely to issue forecasts that reduce dispersion.

In additional tests focused on the short-window returns around earnings announcements, we find that the negative relation between dispersion and announcement returns is incremental to the negative relation of announcement returns with common proxies for differences of opinion (Berkman et al. [2009]). Moreover, the negative relation between dispersion and announcement returns disappears when we control for the ex-post earnings surprise. This result further supports our conclusion that investors' mispricing of predictable variation in earnings surprises helps explain the negative relation between dispersion and returns.

Overall, this study contributes to the literature following Diether et al. [2002] that attempts to explain the relation between analyst dispersion and stock returns. We conclude that investors' mispricing of the predictable pessimistic bias in analysts' forecasts, caused by firms' incentives to meet earnings expectations, provides a viable explanation for the dispersion anomaly. We also contribute to the literature focused on the pricing implications of the earnings expectations game (e.g., Bartov et al. [2002]; Kasznik and McNichols [2002]; Keung et al. [2010]; Abarbanell and Park [2017]; Ma and Markov [2017]; Veenman and Verwijmeren 
[2018]; Johnson et al. [2020]). We demonstrate how and why analyst forecast dispersion can be used to sort firms on the (ex-ante) likelihood that they report earnings that meet analyst expectations, which maps into predictable variation in earnings announcement returns.

Our study complements Berkman et al. [2009], who examine the implications of Miller [1977] for earnings announcement returns. Using five measures of differences of opinion, including analyst dispersion, Berkman et al. [2009] find that firms with high differences of opinion are associated with significantly lower announcement returns than firms with low differences of opinion. They conclude that these lower returns are consistent with earnings announcements correcting the pre-announcement price increases that are induced by the combination of differences of opinion and short-sale constraints. Our study helps explain why the results on analyst dispersion in Berkman et al. [2009] are less consistent with Miller [1977] than the results based on their other variables of differences of opinion. ${ }^{3}$

Besides the role of short-sale constraints, Diether et al. [2002] suggest that analysts' incentives for forecast optimism could also explain the dispersion anomaly. They conjecture that analysts' self-selection in their coverage of firms (e.g., McNichols and O'Brien [1997]) can induce an optimistic bias in market earnings expectations that subsequently corrects and leads to negative return patterns. ${ }^{4}$ A major downside of this suggested explanation based on forecast optimism, however, is that it is difficult to reconcile with the systematic tendency for analysts' forecasts to be pessimistic instead of optimistic at the time of the earnings announcement (e.g., Richardson et al. [2004]; Ke and Yu [2006]; Chan et al. [2007]; Zweig [2018]). We find that investor mispricing of firms' propensity to meet analysts' pessimistic earnings expectations provides a more viable explanation for the dispersion anomaly.

\footnotetext{
${ }^{3}$ Specifically, Berkman et al. [2009] do not find that dispersion is significantly more negatively related to announcement returns in the presence of greater short-sale constraints (their Table 3, Panel B). In addition, they find no evidence of significant overvaluation before earnings announcements for firms with high dispersion and short-sale constraints (their Table 7). In our Online Appendix, we corroborate their results that short-sale constraints do not moderate the negative relation between dispersion and announcement returns during our sample period, and that dispersion is not associated with pre-announcement price increases.

${ }^{4}$ Hwang and $\mathrm{Li}$ [2017] similarly argue that the relation between dispersion and future returns, which they find extends to a large international sample of firms, is consistent with analysts' incentives for forecast optimism and the self-selection in coverage.
} 


\section{On the link between analyst dispersion and the earnings expectations game}

We propose that firms' incentives to meet or beat analyst earnings expectations, and analysts' incentives to help firms achieve that objective, provide an explanation for the dispersion anomaly. We argue that the strategic behavior of firms and analysts in the earnings expectations game induces both higher returns around earnings announcements and lower forecast dispersion.

The link between the earnings expectations game and stock returns follows from recent studies that find investors fail to fully unravel the pessimistic bias in analyst earnings expectations that is induced by firms' and analysts' strategic behavior (e.g., Veenman and Verwijmeren [2018]; Johnson et al. [2020]). For example, Johnson et al. [2020] find that a proxy for firms' expectations management incentives is positively related to analyst-based earnings surprises and the returns in expected earnings announcement months, while it is negatively related to returns in the previous month when expectations are managed downward. Similarly, Veenman and Verwijmeren [2018] show that measures of analysts' past forecast pessimism are positively related to earnings surprises and announcement returns. The results from these studies are consistent with investors mispricing the predictable bias in firms' earnings surprises.

Prior research has also documented significant negative relations between forecast dispersion and firms' propensity to meet analyst expectations. However, these relations are typically incidental to the main research question and therefore not well understood. ${ }^{5}$ In the next two subsections, we propose two related explanations for this negative relation. Figure 1 presents causal diagrams to illustrate our argumentation based on directed acyclic graphs (Pearl [1995]; Morgan and Winship [2015]; Gow et al. [2016]).

\footnotetext{
${ }^{5}$ Specifically, prior research has found significantly negative coefficients on analyst dispersion when used as a control variable in regressions explaining firms' likelihood of meeting analyst expectations. See, for example, Barton and Simko [2002, Table 5], Heflin and Hsu [2008, Table 5], or Jiang et al. [2010, Table 3]).
} 


\subsection{Within-quarter effect of expectations management on forecast dispersion}

Firms can provide earnings guidance to manage analyst expectations. Cotter et al. [2006] find that public earnings guidance lowers the consensus forecast and increases firms' ability to meet analyst expectations, which is consistent with analysts' willingness to be misguided by managers (Feng and McVay [2010]; Ciconte et al. [2014]). The consequence of such guidance is that it increases the precision of common information available to analysts, which lowers analyst dispersion (Barron et al. [1998]). Clement et al. [2003] and Bowen et al. [2002] empirically confirm that increases in the precision of analysts' common information through earnings guidance and conference calls, respectively, reduce forecast dispersion. Houston et al. [2010] and Chen et al. [2011] further find that forecast dispersion increases when firms stop providing public earnings guidance. Hence, public guidance induces both lower analyst dispersion and a greater likelihood that firms report earnings that meet analyst expectations. ${ }^{6}$ Panel A of Figure 1 visualizes these conceptual links.

\subsection{Across-quarter effect of the expectations game on forecast dispersion}

The previous discussion revolved around the effects of expectations management on analyst dispersion within a firm-quarter. However, the earnings expectations game repeats across quarters and this leads to persistent biases in earnings surprises and analysts' forecasts over time (e.g., Matsumoto [2002]; Veenman and Verwijmeren [2018]). To the extent that analysts strategically issue pessimistic forecasts in one period to increase their access to management in the next period (Ke and Yu [2006]; Hilary and Hsu [2013]), this access to management should increase the precision of the average analyst's information and therefore

\footnotetext{
${ }^{6} \mathrm{~A}$ decrease in dispersion can also follow from private earnings guidance. Irani and Karamanou [2003] and Mohanram and Sunder [2006] find that dispersion increased after Regulation Fair Disclosure (Reg FD) banned firms' explicit use of private earnings guidance to individual analysts. Similarly, Wang [2007] finds that firms that did not replace their private guidance with public guidance after Reg FD experience significant increases in analyst dispersion. Combined with the positive effect of private guidance on firms' ability to meet earnings forecasts (Hutton [2005]; Matsumoto [2002]), this suggests that private guidance also induces a negative relation between dispersion and firms' propensity to meet analyst expectations. Although the observed empirical relations in our paper can partly reflect the effect of private guidance, we do not attempt to empirically isolate this effect.
} 
decrease dispersion (Barron et al. [1998]). Accordingly, we argue that analysts' strategic forecast pessimism further strengthens the negative relation between forecast dispersion and firms' propensity to meet or beat expectations over time.

Another issue is that managers have incentives to both meet analyst expectations and to limit the magnitude and volatility of earnings surprises (Graham et al. [2005]; Cheong and Thomas [2018]). In this regard, Durtschi and Easton [2005] conclude that analysts' pessimistic forecast errors are much smaller in magnitude than their optimistic forecast errors. Smaller earnings surprises in prior quarters make firms' earnings more predictable relative to the prevailing consensus forecast in the current quarter and, given analysts' incentives to issue forecasts close to the consensus (e.g., Trueman [1994]; Hong et al. [2000]), this increased predictability and herding should reduce current-quarter dispersion (Liu and Natarajan [2012]). Hence, we argue that firms that consistently meet analysts' pessimistic expectations should also display relatively low analyst dispersion over time. Panel B of Figure 1 visualizes these conceptual links.

\section{Research design}

\subsection{Variable measurement}

Following Diether et al. [2002], we measure forecast dispersion using the standard deviation of analysts' annual earnings forecasts obtained from the IBES Unadjusted Summary History files, scaled by the absolute value of the mean consensus forecast (i.e., the coefficient of variation). When the mean consensus forecast is zero, we set the dispersion variable $\left(\operatorname{Disp}_{t}\right)$ equal to the maximum sample value such that these observations end up in the highest dispersion portfolio. We measure dispersion in the month before we measure stock returns and earnings announcement news. Similar to Berkman et al. [2009], we also construct $D i s p Q_{t}$ based on the standard deviation of analysts' quarterly earnings forecasts.

We compute a firm's quarterly earnings surprise $\left(\right.$ Surprise $\left._{t}\right)$ as the difference between actual earnings, obtained from the IBES Unadjusted files, and the mean consensus forecast 
based on individual analysts' latest forecasts from the IBES Unadjusted detail files. To construct this consensus forecast, we eliminate forecasts older than 180 days and adjust forecasts for stock splits occurring between the forecast date and the earnings announcement date using the CRSP cumulative factor to adjust prices. ${ }^{7}$ Based on Surprise $_{t}$, we construct an indicator variable Meet $_{t}$ that is set equal to 1 if the earnings surprise is non-negative, and 0 if it is negative.

For our monthly return tests, we follow Johnson et al. [2020] in estimating firms' expected earnings announcement months using the date of the same-quarter earnings announcement one year earlier. This procedure relies on information that is available at the time of portfolio formation and ensures that the results are not influenced by the (ex-post) timing of earnings announcements (e.g., Cohen et al. [2007]).

For our tests explaining short-window announcement returns, we identify firms' actual earnings announcement dates by picking the earliest of the Compustat and IBES announcement dates (Dellavigna and Pollet [2009]) and by eliminating observations for which Compustat and IBES disagree about the announcement date by more than two trading days. We also adjust announcements identified as occurring after market close to the subsequent trading day using the IBES timestamps (Johnson and So [2018]). Given these procedures, we measure the market reaction to earnings announcements starting on the day of announcement. Variable $B H A R_{t}^{[0,2]}$ equals the buy-and-hold size-adjusted returns measured from the date of the earnings announcement through two days after the earnings announcement, where sizeadjusted returns are computed relative to the CRSP value-weighted market capitalization index based on NYSE/AMEX/NASDAQ cutoffs.

To test the role of firms' participation in the earnings expectations game in explaining the dispersion anomaly, we rely on ex-ante variables of firms' propensity to meet or beat

\footnotetext{
${ }^{7}$ Following Diether et al. [2002], we rely on the IBES data that is unadjusted for stock splits in order to properly identify cases where firms meet versus miss consensus analyst expectations. Relying on IBES data adjusted for splits, which are rounded to the nearest cent, would lead to a non-trivial number of observations being transformed to (rounded) $0 c$ earnings surprises, while instead the firm beat or missed the consensus forecast. We adjust the unadjusted forecasts for stock splits using the CRSP split factor (CFACPR) in order to better align the (unrounded) forecasts and actuals.
} 
earnings expectations from recent studies. First, Johnson et al. [2020] create a composite measure of firms' expectations management incentives (EMI) and find that this measure is positively related to earnings surprises, positively related to returns in expected earnings announcement months, and negatively related to returns in the prior month when expectations are managed downward. Following their work, we construct a parsimonious measure of expectations management incentives based on a monthly principal component analysis of variables capturing incentives to manage expectations $\left(E M I_{t-1}\right)$.

We start by measuring EMI using proxies for the "attention" to earnings news: analyst coverage and institutional investor ownership. Johnson et al. [2020] show that these variables explain the bulk of the variation in their EMI measure and primarily drive the return patterns they uncover. Next, to proxy for the "pressure" to meet expectations and the "relevance" of earnings news for stock prices, we use a simple variable that captures the fraction of losses reported in the most recent 12 quarters. Prior work suggests profitable firms face greater incentives to report positive earnings surprises (Brown [2001]; Matsumoto [2002]), while the stock prices of profitable firms are more sensitive to earnings news than those of loss-making firms due to shareholders' abandonment option (Hayn [1995]). ${ }^{8}$

Second, Veenman and Verwijmeren [2018] find that measures of analysts' prior forecast pessimism (PESS) can be used to assess the extent of pessimism in the current-quarter consensus forecast, and similarly find that these measures predict both firms' propensity to meet earnings expectations and the returns around earnings announcements. We replicate their two ex-ante measures of analyst forecast pessimism: $P E S S_{t-1}^{C}$ is based on pessimism versus optimism in the firm's previous consensus forecasts, and $P E S S_{t-1}^{I}$ is based on pessimism versus optimism in the individual analysts' previous forecasts. See Appendix A for more

\footnotetext{
${ }^{8}$ Following Johnson et al. [2020], we transform the input variables to monthly percentile ranks scaled between 0 and 1 before we estimate $E M I_{t-1}$ as the first principal component in each sample month. Consistent with the prediction that analyst coverage and institutional ownership are positively related to EMI, while loss frequency is negatively related to EMI, the first two variables load positively (average weights of 0.669 and 0.662 , respectively) and the third component loads negatively (average weight of -0.317) in the principal component analysis. The inferences in our paper are similar when we use the EMI measure from https://doi.org/10.1093/rfs/hhz141, which is available only for a subset of our data and sample period.
} 
details on the construction of the EMI and PESS variables.

We use both the EMI and PESS variables because we consider them as complementary indicators of firms' participation in the earnings expectations game. While the EMI measure captures firms' incentives to manage expectations to beatable levels (e.g., through downward earnings guidance), the PESS measures additionally capture analysts' desire to curry favor with firm management by lowballing their forecasts. Consistent with each variable capturing different dimensions of the earnings expectations game, the time-series average of monthly correlations of $E M I_{t-1}$ with $P E S S_{t-1}^{C}$ and $P E S S_{t-1}^{I}$ equal 0.274 and 0.210 , respectively. The average correlation between $P E S S_{t-1}^{C}$ and $P E S S_{t-1}^{I}$ equals 0.396 . As we

demonstrate later, each variable has incremental predictive power for the returns around earnings announcements.

\subsection{Data}

Table 1 presents the sample selection procedures. For our monthly return tests, we obtain security-month observations from CRSP for firms listed on NYSE, AMEX, or NASDAQ. To mirror our examination of announcement news for firm-quarters ending in calendar quarters 1993Q1 through 2018Q4 (see below), our sample comprises the 312 months from April 1993 through March 2019. We include delisting returns from CRSP and adjust for missing delisting returns following Shumway and Warther [1999]. We retain only those observations with a stock price of at least $\$ 1$ at the end of the previous month and attach the previous-month forecast dispersion from IBES. These procedures lead to a sample of 971,213 monthly return observations, of which 295,606 are expected earnings announcement months. After requiring additional data on size, book-to-market, prior returns, and the EMI and PESS measures, the expected earnings announcement-month sample comprises 277,690 observations.

For our quarterly announcement sample, we obtain firm-quarters from the intersection of CRSP and Compustat that end in the calendar quarters 1993Q1 through 2018Q4. We drop firms not listed on NYSE, AMEX, or NASDAQ, firms with quarter-end stock price 
below $\$ 1$, and firms missing earnings announcement dates in Compustat (RDQ). We next drop observations missing earnings surprise data in IBES and observations missing earnings announcement return data in CRSP. After eliminating all firm-quarters without dispersion variables available and missing data for the control variables, we have a sample of 290,774 firm-quarter observations over the period 1993Q1 to 2018Q4. ${ }^{9}$ In the Online Appendix, we present insights on the sample composition over time and show that firms in our sample meet earnings expectations in roughly two-thirds of cases.

\section{Analyst dispersion, stock returns, and earnings announcements}

\subsection{Replicating the dispersion anomaly}

In Table 2, we first present a re-examination of the general relation between forecast dispersion and returns in our sample. We do this using the dispersion of annual earnings forecasts in Panel A, and based on quarterly forecasts in Panel B. We perform this reexamination because recent studies demonstrate that many variables have lost their returnpredictive power due to more liquid markets and general knowledge of these signals following initial publication (e.g., Green et al. [2011]; Chordia et al. [2014]; McLean and Pontiff [2016]).

Table 2 presents the time-series averages of returns for monthly quintile portfolios formed based on dispersion. ${ }^{10}$ Consistent with Diether et al. [2002], we find that low-dispersion firms experience higher returns than high-dispersion firms. For example, based on the dispersion in annual earnings forecasts in Panel A, firms in Q1 earn significant average returns of 0.91 percent, while firms in Q5 earn insignificant average returns of 0.48 percent. Although the average return difference between the low- and high-dispersion portfolios of 0.43 percent is statistically insignificant in Panel A ( $p$-value: 0.130), it is significant in Panel B based on the dispersion in quarterly forecasts ( $p$-value: 0.036$).{ }^{11}$

\footnotetext{
${ }^{9}$ Note that this quarterly announcement sample is larger than the monthly return dataset because we do not require data on the EMI and PESS measures for this sample.

${ }^{10}$ Throughout the paper, standard errors of the average estimates are adjusted for autocorrelation using the Newey and West [1987] adjustment with five lags.

${ }^{11}$ Consistent with Diether et al. [2002], we also find that these return differences are greatest for smaller firms. When we split the sample into larger and smaller firms based on the monthly median lagged market
} 
When we perform calendar-time portfolio regressions based on the Fama-French fourfactor model, we find that the monthly risk-adjusted return differences (alphas) increase to 0.55 and 0.52 in Panels $\mathrm{A}$ and $\mathrm{B}$, respectively, and become statistically more significant ( $t$-values of 3.34 and 3.98, respectively). Although smaller than the 0.79 percent originally reported by Diether et al. [2002], these results suggest that the dispersion anomaly exists even during our more recent sample period. In addition, it is worth mentioning that while highdispersion firms earn significantly negative abnormal returns (the short side), low-dispersion firms actually earn significantly positive abnormal returns (the long side).

We next split the sample into earnings announcement and non-earnings announcement months. Because we argue that the link between dispersion and firms' propensity to meet earnings expectations plays a role in explaining the dispersion anomaly, we expect return differences to be concentrated around earnings announcements. Doing so, we find significant return differences for both dispersion variables only in expected earnings announcement months. Based on the dispersion in annual (quarterly) forecasts in Panel A (Panel B) of Table 2, we find statistically significant return differences equal to 0.65 percent (0.60 percent). Return differences are small and insignificant in the other months, and the rightmost column in Panels A and B reveal that the differences in return spreads between earnings and nonearnings announcement months are statistically significant. These return differences become even stronger when we focus on actual earnings announcement months.

Similar to Berkman et al. [2009], we also find that forecast dispersion is significantly related to short-window announcement returns. In Panel A (Panel B) of Table 2, firms with low annual (quarterly) forecast dispersion have announcement returns that are 0.61 percent (0.53 percent) higher compared to firms with high forecast dispersion. Importantly, a comparison of the full announcement-month returns with the short-window returns suggests that the bulk of the return difference is concentrated around the earnings announcement. To

capitalization, we find (untabulated) significant return differences for the smaller sample firms of 0.66 ( $t$ value of 2.89) and 0.65 ( $t$-value of 3.77) percentage points based on annual and quarterly forecast dispersion, respectively. Return differences are small and insignificant for the larger sample firms. Note, however, that these "smaller" firms are still relatively large as they are required to be covered by at least two analysts. 
further evaluate this observation, we examine differences in average portfolio returns after we adjust the announcement-month returns for the short-window announcement returns. Doing so, the announcement-month return differences reduce to -0.014 and 0.004 percent in Panels A and B, respectively.

Overall, the descriptive results in Table 2 provide evidence consistent with the dispersion anomaly. In addition, they suggest that the return predictability of forecast dispersion is a phenomenon that concentrates primarily around earnings announcements.

\subsection{Cross-sectional regressions}

In this section, we examine the relation between expected announcement-month returns and dispersion after controlling for other return-predictive variables. We first control for standard measures of firm size $\left(\right.$ Size $\left._{t}\right)$, book-to-market $\left(B t M_{t}\right)$, and prior returns $\left(\operatorname{Ret}_{t-1}\right.$ and $\left.\operatorname{Ret}_{t-2, t-12}\right)$. Next, we additionally control for leverage $\left(\operatorname{Lev}_{t}\right)$, firm age $\left(A g e_{t}\right)$, analyst coverage (Analysts $s_{t}$, and institutional ownership (Inst ${ }_{t}$ ), and include three variables for differences of opinion examined by Berkman et al. [2009]: the standard deviation of daily returns measured over the period from 55 through 11 days before the expected announcement month $\left(\right.$ Retvol $\left._{t}\right)$; the volatility of earnings in the previous 20 quarters $\left(\right.$ Evol $\left._{t}\right)$; and turnover, measured as the average daily ratio of trading volume to shares outstanding in the window from 55 through 11 days before the expected announcement month $\left(\right.$ Turn $\left._{t}\right)$. We include these last three variables to assess the extent to which the relation between dispersion and announcement returns is unique and incremental to measures of differences of opinion.

Panel A of Table 3 presents results from monthly cross-sectional regressions (Fama and MacBeth [1973]). We transform all independent variables to decile ranks scaled between -0.5 and 0.5 , such that each coefficient captures the difference in average announcement returns between firms in the highest and lowest deciles (e.g., Livnat and Mendenhall [2006]). The

results reveal significant differences in returns between high- and low-dispersion firms. Based on annual (quarterly) forecast dispersion and the standard controls for size, book-to-market, 
and prior returns, low-dispersion firms have monthly returns that are 61 (62) basis points higher than high-dispersion firms. These return spreads remain remarkably stable, and strengthen in statistical significance, after we add the other set of control variables including the differences-of-opinion variables from Berkman et al. [2009]. ${ }^{12}$

Next, we examine the effects of including the EMI and PESS measures in the regressions. If the negative relation between dispersion and returns in expected announcement months is driven by firms' participation in the earnings expectations game, we should observe the negative relation to be attenuated after proxies for this participation are included in the regressions. This is exactly what we find. After including $E M I_{t-1}, P E S S_{t-1}^{C}$, and $P E S S_{t-1}^{I}$, the coefficients on the dispersion variables drop by more than half and are no longer statistically significant at $p<0.05$. Moreover, the EMI and PESS variables are each associated with significant incremental return spreads. These results provide initial support for our prediction that investor mispricing of variation in firms' propensity to meet or beat earnings expectations provides an explanation for the dispersion anomaly.

\subsection{Alternative explanation based on short-sale constraints}

Nagel [2005] finds some evidence that the negative relation between dispersion and future returns is concentrated among firms with more binding short-sale constraints, which is consistent with the proposed explanation for the dispersion anomaly by Diether et al. [2002] based on Miller [1977]. Berkman et al. [2009] perform a similar test using earnings announcement returns, but find no significant difference in dispersion return spreads between firms with high and low short-sale constraints (their Table 3). In the Online Appendix, we use institutional ownership as an inverse proxy for short-sale constraints. Consistent with both Berkman et al. [2009] and a reduced relevance of short-sale constraints in recent sample

\footnotetext{
${ }^{12}$ The risk-based explanation proposed by Johnson [2004] suggests that the negative relation between dispersion and returns should be increasing in firms' leverage. Inconsistent with this prediction, in untabulated tests we find no evidence of a more negative relation between dispersion and announcement returns when we interact the dispersion variable with leverage in our cross-sectional regressions. Berkman et al. [2009] and Avramov et al. [2009] similarly find no significant interaction effect based on leverage.
} 
periods, we find no evidence that suggests short-sale constraints explain the relation between analyst dispersion and earnings announcement returns in our sample.

\subsection{Explaining dispersion with EMI and PESS measures}

Panel A of Table 4 shows that, consistent with Johnson et al. [2020] and Veenman and Verwijmeren [2018], $E M I_{t-1}, P E S S_{t-1}^{C}$, and $P E S S_{t-1}^{I}$ are strongly related to firms' propensity to meet expectations and the returns in expected announcement months. For example, firms in the highest quintile of $E M I_{t-1}$ are on average 14.3 percentage points more likely to report a non-negative earnings surprise, whereas monthly return spreads range from 80 basis points for $P E S S_{t-1}^{C}$ to 89 basis points for $E M I_{t-1}$. We also find strong negative associations of the measures with the dispersion variables. For example, the time-series average of the monthly median value of annual forecast dispersion of firms in the highest (lowest) $P E S S_{t-1}^{C}$ quintile equals 0.021 (0.084). These results confirm that the EMI and PESS measures are relevant in understanding the relation between dispersion and returns.

In Panel B of Table 4, we estimate monthly cross-sectional regressions of forecast dispersion on the EMI and PESS measures. The regression results confirm the strong negative relations found in Panel A and indicate that each measure has a significant incremental relation with dispersion. These results suggest that firms that are more likely to be involved in the earnings expectations game, as indicated by higher expectations management incentives and pessimistic analyst forecasts, are also associated with significantly lower forecast dispersion. We next use the regressions that include $E M I_{t-1}, P E S S_{t-1}^{C}$, and $P E S S_{t-1}^{I}$ to construct fitted and residual values of forecast dispersion. We employ these fitted and residual values of forecast dispersion to predict returns and to isolate the effect of the dispersion component that relates to the earnings expectations game.

The results in Panel $\mathrm{C}$ of Table 4 show that the negative relation between dispersion and returns is driven by the fitted values of dispersion. The portion of forecast dispersion that is explained by the three variables has strong predictive power for announcement returns, 
with monthly return spreads of $112-122$ basis points. In contrast, the residual values are not significantly associated with returns. When the fitted and residual dispersion variables are combined in one regression, we find that the announcement return spreads based on fitted dispersion are significantly different from the spreads based on residual dispersion.

Although the first-stage regression results in Panel B of Table 4 suggest that the EMI and PESS measures explain only a small part of the variation in dispersion (the average explanatory power equals 14.7 (9.4) percent for annual (quarterly) dispersion), the results in Panel $\mathrm{C}$ reveal that this small component of dispersion explains all of the expected announcementmonth return spreads associated with dispersion. Combined with the observation that the return spreads concentrate around earnings announcements, these results are consistent with the prediction that the dispersion anomaly can be explained by the relation between dispersion and firms' participation in the earnings expectations game.

\subsection{Portfolio tests of fitted and residual dispersion measures}

To provide more economic context to the results presented in the previous section, we conduct Fama-French regressions of portfolio returns on risk factors. For each expected earnings announcement month, we construct quintile portfolios based on the lagged values of fitted and residual dispersion and compute average (equal-weighted) portfolio returns by quintile for each of the 312 months in our sample.

We estimate calendar-time portfolio regressions using a Fama-French four-factor model that we augment with an earnings announcement risk factor $(E A R F)$ similar to Chang et al. [2017] and Johnson et al. [2020]. We include this additional factor because an alternative explanation for the differences in returns for firms with high and low dispersion could be that firms have different exposures to earnings announcement premia. Prior studies such as Ball and Kothari [1991] and Cohen et al. [2007] find that firms earn significantly higher returns around their earnings announcement dates. EARF is defined as the monthly difference in value-weighted returns between firms that are expected to announce earnings and those that 
are not expected to announce earnings.

The results in Table 5 suggest that portfolios based on the fitted values of dispersion produce statistically and economically significant risk-adjusted returns in expected earnings announcement months. Based on fitted annual (quarterly) forecast dispersion in Panel A (Panel B), monthly risk-adjusted return spreads equal 94 (108) basis points. ${ }^{13}$ Moreover, a large part of the return spreads is realized on the long side of the portfolio, as the Q1 (low fitted dispersion) portfolio has an alpha of 57 (65) basis points. In contrast, the return spreads are insignificant at 16 (25) basis points for portfolios formed based on residual dispersion, and the differences in return spreads between the portfolios formed on fitted versus residual dispersion are highly significant.

These results suggest that isolating the variation in analyst dispersion that relates to firms' propensity to meet earnings expectations produces economically large return differences that are not explained by standard risk factors. For example, the loadings on EARF are insignificant for the hedge portfolios formed on fitted dispersion, suggesting the return spreads are not explained by earnings announcement premia. The loadings on MKTRF suggest the fitted dispersion portfolio returns are orthogonal to the market factor, while the negative loading on $S M B$ and weak positive loading on $U M D$ are consistent with both Veenman and Verwijmeren [2018] and Johnson et al. [2020].

\subsection{Differences in returns in pre-earnings announcement months}

To provide some more insights into the nature of the mispricing that explains the dispersion anomaly, in the Online Appendix we also examine return predictability based on EMI and PESS in month $t-1$. As discussed in Section 3.1, EMI and PESS measure complementary aspects of the earnings expectations game. While expectations management and forecast pessimism have similar implications for the predictability of earnings surprises and

\footnotetext{
${ }^{13}$ Consistent with the dispersion anomaly and investor mispricing of forecast pessimism being stronger in smaller firms (Diether et al. [2002]; Veenman and Verwijmeren [2018]), untabulated tests reveal that the value-weighted risk-adjusted portfolio returns are somewhat smaller at 67 basis points for both annual and quarterly forecast dispersion, respectively, but still significant with $t$-values equal to 2.61 and 2.85 .
} 
announcement returns, and therefore have similar implications for the relation between dispersion and announcement returns, the expected relations with returns in the period before earnings announcements differ. In the Online Appendix, we explain the conceptual intuition behind this prediction and show how EMI and PESS have different relations with the returns in pre-earnings announcement months. Consistent with Johnson et al. [2020], we find that portfolios sorted by the EMI measure produce significant return spreads in month $t-1$ in the opposite direction of those observed for month $t$. In contrast, we do not find significant return spreads in month $t-1$ when we focus on the PESS measures. These results suggest that the mispricing induced by expectations management manifests in the period before the earnings announcement (and reverses at the earnings announcement), while the mispricing induced by forecast pessimism manifests at the earnings announcement. ${ }^{14}$

\section{Additional tests based on earnings announcement data}

\subsection{Forecast dispersion and short-window earnings announcement returns}

In Table 6, we turn to our sample of firm-quarters to assess the relation between dispersion and announcement-window returns $\left(B H A R_{t}^{[0,2]}\right)$ in a multiple regression framework. Although the results in Table 3 suggest that the alternative differences-of-opinion variables (return volatility, earnings volatility, and turnover) have no significant incremental relation with monthly returns, Berkman et al. [2009] conclude that these variables are strongly negatively related to short-window announcement returns. Moreover, by focusing on the actual earnings announcement we can examine the effects of controlling for the ex-post earnings surprise.

The control variables included in the regressions are similar to those included in Table 3,

\footnotetext{
${ }^{14}$ PESS might be associated with a reversal of mispricing after earnings announcements. However, the most likely event at which the mispricing could reverse is at the subsequent earnings announcement, which is when firms with PESS-induced positive earnings surprises typically report another positive earnings surprise. Our tests in the Online Appendix support this lack of a reversal of mispricing. We find that the returns for high-PESS firms significantly exceed those of low-PESS firms when we examine all months unconditionally (i.e., when we do not condition on the month being an (expected) announcement month). This result is in line with prior research that finds that firms that meet expectations have higher full-quarter returns than firms that miss expectations (e.g., Bartov et al. [2002]; Kasznik and McNichols [2002]).
} 
except that we replace the prior return variables by short-window returns measured before the earnings announcement. Because dispersion can be viewed as a measure of information uncertainty before earnings announcements, we include the daily size-adjusted returns before the earnings announcement to control for information-driven return reversals (So and Wang [2014]; Levi and Zhang [2015]). We include separate variables for the five daily abnormal returns before the earnings announcement date $\left(A R_{t}^{[-\tau]}\right)$, as well as the buy-and-hold ab-

normal returns measured from day -10 through $-6\left(B H A R_{t}^{[-10,-6]}\right)$. Moreover, the return volatility and turnover variables are now measured relative to the earnings announcement date instead of the start of the announcement month.

We first present results without controlling for differences-of-opinion measures. The results reveal significant differences in announcement returns between high- and low-dispersion firms. Based on annual (quarterly) forecast dispersion, low-dispersion firms have three-day announcement returns that are 63 (56) basis points higher than high-dispersion firms. These return differences become somewhat smaller when we include the differences-of-opinion variables, which suggests that analyst dispersion shares predictive power for short-window announcement returns with these variables. Still, the return differences between low- and high-dispersion firms remain significant over the short window (32 and 31 basis points based on annual and quarterly forecast dispersion, respectively, with $t$-values of 3.77 and 4.41 ).

Lastly, we control for the value of the earnings surprise (Surprise ${ }_{t}$ ) and find that the significant negative relation between dispersion and announcement returns disappears. This result is consistent with biased earnings expectations explaining the negative relation of dispersion with announcement returns.

\subsection{Evidence on the mechanism}

\subsubsection{Dispersion and firms' ex-post propensity to meet or beat expectations}

In this section we examine the association between analyst dispersion and firms' expost meeting or beating of analyst expectations, while controlling for the other variables 
included in Table 6. The only adjustment we make to the control variables is that we aggregate the individual daily pre-announcement return variables and extend the return variable measurement to 60 trading days. This adjustment controls for the result that analysts' forecasts tend to be relatively stale by the time of the earnings announcement, which leads to predictable variation in earnings surprises.

Panel A of Table 7 presents the results from quarterly logit regressions of an indicator variable Meet $_{t}$, which is set equal to 1 for firms that meet expectations, and 0 otherwise, on forecast dispersion and control variables. The results suggest both annual and quarterly forecast dispersion variables are strongly negatively related to firms' propensity to meet expectations. Holding all else constant, firms in the lowest decile of dispersion are 22-23 percentage points more likely to report earnings that meet analyst expectations than firms in the highest decile of dispersion.

Among the control variables, the only variable that comes close to the predictive power of dispersion is the lagged return variable. Consistent with the staleness of the analyst consensus, firms in the highest return decile are 18 percentage points more likely to meet expectations. The marginal effects of the other variables are substantially weaker. For example, among the differences-of-opinion variables from Berkman et al. [2009], only return volatility has a significant negative association with meeting expectations. In terms of magnitude, however, the association of dispersion with meeting expectations is more than five times as strong. Earnings volatility is instead significantly positively associated with meeting expectations, while the coefficients on turnover are insignificant. These results suggest that analyst dispersion relates to announcement returns through a different mechanism than the differences-of-opinion measures of Berkman et al. [2009].

Figure 2 provides additional insights into the relation between dispersion and earnings surprises. For the firms in portfolios Q1 (low dispersion) and Q5 (high dispersion) based on annual forecast dispersion, we separately plot the frequency distribution of earnings surprises. The low-dispersion firms clearly have a substantially stronger asymmetry in the 
earnings surprise distribution compared to high-dispersion firms. Consistent with Bissessur and Veenman [2016], low-dispersion firms are more likely to just beat quarterly earnings expectations and high-dispersion firms are more likely to just miss expectations. The striking difference in the frequency distributions underscores the strong link between dispersion and firms' propensity to meet earnings expectations.

\subsubsection{Explanations for the link between analyst dispersion and meet-or-beat incidence}

This section presents tests of the mechanisms we proposed in Section 2. In Panel B of Table 7, we examine firms' use of public guidance to explain the within-quarter negative relation between analyst dispersion and meeting expectations. These tests are similar in spirit to those from Cotter et al. [2006], who examine how public guidance relates to preguidance forecast dispersion and how guidance affects firms' ability to meet expectations. We extend these tests to examine how guidance affects dispersion. Similar to Cotter et al. [2006], we use a firm- and time-fixed effects design to test how variation in a firm's decision to provide public guidance $\left(\right.$ Guide $\left._{t}\right)$ affects dispersion and the propensity to meet expectations.

For each of the firm-quarters in our sample of firms that provide earnings guidance at least once during the post-1998 period (Chuk et al. [2013]), we create two data points and measure Meet $_{t}$ and $D i s p Q_{t}$ using the consensus forecast measured either 120 days or 1 day before the earnings announcement. We next create an indicator variable Post that is set equal to 1 for those data points measured 1 day before the earnings announcement (i.e., postguidance), and 0 for data points measured 120 days before the earnings announcement. The coefficient on the interaction between Guide $_{t}$ and Post $_{t}$ provides the difference-in-difference estimator, which quantifies the within-firm-quarter effect of guidance on dispersion. ${ }^{15}$

The baseline results are consistent with Cotter et al. [2006]. First, firm-quarters with guidance are associated with more optimistic initial forecasts as guiding firms are less likely

\footnotetext{
${ }^{15}$ The results are similar (untabulated) when we include firm-year-quarter fixed effects. We display the results using separate firm- and year-quarter fixed effects because it allows us to tabulate and interpret the main effect on Guide.
} 
to meet the day -120 consensus forecast. Second, the positive significant interaction between Guide $_{t}$ and Post $_{t}$ in the first column suggests that guidance significantly enhances firms' ability to meet expectations. Third, firm-quarters with guidance are associated with significantly lower dispersion at the beginning of the quarter. Most importantly, these tests reveal that public guidance significantly lowers forecast dispersion. The negative coefficient on Guide $\times$ Post $_{t}$ indicates that the general reduction in dispersion before the earnings announcement is significantly stronger when firms provide public earnings guidance, which is consistent with our prediction.

Figure 3 visualizes the effect of public guidance on dispersion. For the 120-day window before the earnings announcement, we plot the average daily dispersion in quarterly earnings forecasts. In the left-hand graph, we plot the trajectory of dispersion separately for firmquarters with and without public earnings guidance. The figure reveals a substantially stronger reduction in forecast dispersion in guidance firm-quarters. Consistent with guidance taking place mostly around the previous-quarter earnings announcement, we also see that this reduction in dispersion materializes most strongly around day -90. The right-hand graph provides similar insights, but now based on firms that are more versus less likely engaged in expectations management given their recent history of meeting or beating expectations.

As further support of the proposed mechanism for the relation between dispersion and firms' propensity to meet expectations, we present the following insights in the Online Appendix. First, we provide descriptive statistics for portfolios formed on firms' recent history of meeting expectations, to provide an understanding of how the repeated nature of the earnings expectations game is associated with reduced analyst dispersion for firms over time. We find that firms with the highest frequency of meeting expectations are associated with significantly less volatile earnings surprises than firms with the lowest frequency. We further find that analysts forecasts closer to the prevailing consensus for firms meeting expectations more frequently, they are more likely to lowball their forecasts by one or two cents below actual earnings, and their forecasts are significantly more likely to reduce forecast dispersion. In 
addition, in tests examining how meeting or beating earnings expectations is associated with dispersion across quarters, we find that meeting or beating expectations in one additional quarter is associated with lower forecast dispersion in the following quarter.

\subsection{Forecast dispersion and pre-earnings announcement returns}

In the Online Appendix, we further differentiate the announcement return differences related to dispersion from earnings announcement premia. Prior research finds that earnings announcement premia materialize primarily in the days before the earnings announcement (Barber et al. [2013]; Johnson and So [2018]). If differences in earnings announcement premia explain the negative relation between earnings announcement returns and dispersion, we should observe a positive relation with returns in the days before the earnings announcement. The results from our analysis suggest there is no significant positive relation between dispersion and pre-announcement returns. In contrast, we find that each of the differencesof-opinion variables from Berkman et al. [2009] has a significant positive association with pre-announcement returns. Hence, we conclude that the return patterns of the dispersion variables around earnings announcements are not consistent with explanations based on differences of opinion or earnings announcement premia.

\section{Summary and conclusions}

This paper extends the set of potential explanations for the dispersion anomaly by examining the role of firms' propensity to meet analyst earnings expectations. We first demonstrate that the negative relation between dispersion and returns is concentrated around earnings announcements. Next, we find that this negative relation disappears when we control for ex-ante measures of firms' propensity to meet earnings expectations based on Johnson et al. [2020] and Veenman and Verwijmeren [2018]. These measures are negatively related to dispersion and positively related to returns, which suggests they are omitted correlated variables in the relation between dispersion and returns. Moreover, despite these ex-ante 
measures explaining only a small portion of the variation in dispersion, we find that the variation of dispersion explained by the measures explains all of the return predictability of dispersion. The residual values of dispersion are not associated with returns, while hedge portfolios based on fitted values produce strong risk-adjusted returns.

Using actual earnings announcement data, we find that firms with low analyst dispersion are significantly more likely to achieve positive earnings surprises and that, relative to other variables, dispersion is an economically strong predictor of firms' propensity to meet expectations. In other words, this result suggests that portfolio sorts of firms by analyst dispersion, as in Diether et al. [2002], also produce sorts on the ex-ante likelihood that firms report earnings that meet analyst expectations. We provide new insights that are consistent with both expectations management and the repeated nature of the earnings expectations game explaining this link. For example, firms that provide public earnings guidance experience significantly greater reductions in forecast dispersion over the quarter than firms that do not provide such guidance.

Overall, our results suggest that investors' inability to fully unravel firms' propensity to play the earnings expectations game provides a viable explanation for the dispersion anomaly. An interesting avenue for future research is to examine how alternative explanations for the dispersion anomaly have varying importance over time. For example, the increased availability of lendable shares in recent years has likely reduced the importance of shortsale constraints as an explanation. Moreover, the growing body of academic insights into the pricing effects of firms' propensity to play the earnings expectations game (Veenman and Verwijmeren [2018]; Johnson et al. [2020]), and related coverage in the financial press (e.g., Gryta et al. [2016]; Zweig [2018]), potentially decrease the magnitude of the dispersion anomaly in the future. 


\section{Appendix A. Variable definitions}

$A g e_{t}=$ Firm age, measured as the number of months since the firm's first appearance in CRSP.

Analyst $_{t}=$ Number of analyst forecasts used to construct the dispersion variable in the monthly data; number of analysts used to construct the current-quarter earnings surprise in the quarterly data.

$A R_{t}^{[-\tau]}=$ Daily size-adjusted return on day $\tau$ relative to the earnings announcement date, where $\tau \in$ $\{-5,-4,-3,-2,-1\}$; size-adjusted returns are computed relative to the CRSP value-weighted market capitalization index based NYSE/AMEX/NASDAQ cutoffs (CRSP file ERDPORT1).

$B H A R_{t}^{[0,2]}=$ Buy-and-hold size-adjusted stock returns for the firm-quarter, measured from the date of the earnings announcement through two days after the earnings announcement.

$B H A R_{t}^{[-\tau,-\theta]}=$ Buy-and-hold size-adjusted returns over trading days $-\tau$ through $-\theta$ relative to the earnings announcement date.

$B t M_{t}=$ Book-to-market ratio, measured using the most recent quarter book value of common equity (Compustat: CEQ) scaled by the market value of equity; where market value is measured in the monthly data using CRSP data and measured in the quarterly data using end-of-quarter Compustat data (Compustat: PRCCQ $\times$ CSHOQ).

$\operatorname{Disp} A_{t}=$ Dispersion in analysts' forecasts of earnings per share (EPS), measured in the previous month using the standard deviation of individual analysts' forecasts of annual EPS obtained from the unadjusted IBES Summary History files $(F P I=1)$, scaled by the absolute value of the mean consensus forecast; for those cases where the mean consensus forecast is zero, $D i s p A_{t}$ is set equal to the maximum sample value.

$\operatorname{Disp} Q_{t}=$ Dispersion in analysts' forecasts of EPS, measured in the previous month using the standard deviation of individual analysts' forecasts of quarterly EPS obtained from the unadjusted IBES Summary History files $(F P I=6)$, scaled by the absolute value of the mean consensus forecast; for those cases where the mean consensus forecast is zero, $\operatorname{Disp} Q_{t}$ is set equal to the maximum sample value.

$E M I_{t-1}=$ Ex-ante measure of expectations management incentives constructed following Johnson et al. [2020] as the first principle component of variables associated with managers' incentives to manage earnings expectations; for each sample month with sufficient data in CRSP and Compustat for firms listed on NYSE, AMEX, or NASDAQ with a lagged stock price of at least $\$ 1$ and an earnings announcement in Compustat 12 months earlier, we rank three variables into percentiles (analyst coverage, institutional ownership, and loss frequency in the most recent 12 (minimum one) quarters, where all variables are measured 12 months earlier) and compute $E M I_{t-1}$ as the first principal component of the monthly percentile ranks.

Evol $_{t}=$ The standard deviation of earnings scaled by total assets (Compustat: IBQ / ATQ) in the previous 20 quarters, with a minimum of four quarters of prior earnings data required.

Guide $_{t}=$ Indicator variable set equal to 1 for firms with earnings guidance, and 0 otherwise, based on guidance identified in the IBES Guidance files in the 120 days before the earnings announcement; this variable is restricted to post-1998 data to alleviate concerns with non-random coverage of earnings guidance (Chuk et al. [2013]).

Inst $_{t}=$ Percentage of a firm's common shares outstanding held by institutions at the end of the most recently completed calendar quarter, from 13-F Filings in the Thomson Reuters' Institutional Holdings Database (S34).

$\operatorname{Lev}_{t}=$ Leverage, measured using the end-of-quarter $t$ ratio of long-term debt (Compustat: DLTT + DLC) 
to total assets (Compustat: ATQ).

Meet $_{t}=$ Indicator variable set equal to 1 if Surprise $_{t}$ is non-negative, 0 otherwise.

$P E S S_{t-1}^{C}=$ Ex-ante measure of consensus analyst forecast pessimism following Veenman and Verwijmeren [2018], measured as the fraction of the previous 12 quarters in which the firm reported earnings per share that beat (Surprise $>0$ ) instead of missed (Surprise <0) consensus analyst expectations, requiring a minimum of four prior nonzero quarterly earnings surprises.

$P E S S_{t-1}^{I}=$ Ex-ante measure of individual analyst forecast pessimism following Veenman and Verwijmeren [2018] based on individual analysts' past forecast errors; this measure is computed from the average frequency with which any firm beat (instead of missed) the individual analyst's forecasts over the preceding 12-month period, which is then aggregated for all individual analysts that cover a particular firm-quarter.

$\operatorname{Ret}_{t}=$ Raw monthly stock return from the CRSP monthly stock files in month $t$.

$\operatorname{Ret} X_{t}^{[0,2]}=$ Raw monthly stock return from the CRSP monthly stock files for a firm's earnings announcement month, adjusted for the raw returns in the earnings announcement window $[0,2]$.

Retvol $_{t}=$ The standard deviation of daily size-adjusted returns measured over the period from 55 through 11 days before the (expected) earnings announcement (month).

$S_{i z e}=$ Firm size based on market capitalization; measured in the monthly data using CRSP data; measured in the quarterly data using end-of-quarter $t$ stock price (Compustat: PRCCQ) multiplied by the total number of shares outstanding (Compustat: CSHOQ).

Surprise $_{t}=$ Actual EPS for the firm-quarter obtained from the IBES Unadjusted files, less the mean consensus forecast measured using each individual analyst's latest forecast from the IBES detail files; forecasts older than 180 days are eliminated; the forecasts are adjusted for stock splits between the forecast date and earnings announcement dates using the CRSP cumulative factor to adjust prices (CFACPR).

Turn $_{t}=$ Turnover, measured as the average daily ratio of trading volume to shares outstanding in the window from 55 through 11 days before the (expected) earnings announcement (month). 


\section{References}

Abarbanell, J., and H. PARK. 'Do Bright-Line Earnings Surprises Really Affect Stock Price Reactions?' Management Science 63 (2017): 1063-1084.

Avramov, D., T. Chordia, G. Jostova, and A. Philipov. 'Dispersion in Analysts' Earnings Forecasts and Credit Rating.' Journal of Financial Economics 91 (2009): 83-101.

Ball, R., and S. P. Kothari. 'Security Returns around Earnings Announcements.' The Accounting Review 66 (1991): 718-738.

Barber, B. M., E. T. De George, R. Lehavy, and B. Trueman. 'The Earnings Announcement Premium Around the Globe.' Journal of Financial Economics 108 (2013): 118-138.

Barinov, A. 'Analyst Disagreement and Aggregate Volatility Risk.' Journal of Financial and Quantitative Analysis 48 (2013): 1877-1900.

Barron, O. E., O. Kim, S. C. Lim, and D. E. Stevens. 'Using Analysts' Forecasts to Measure Properties of Analysts' Information Environment.' The Accounting Review 73 (1998): 421-433.

Barron, O. E., M. H. Stanford, and Y. Yu. 'Further Evidence on the Relation between Analysts' Forecast Dispersion and Stock Returns.' Contemporary Accounting Research 26 (2009): 329-357.

Barton, J., and P. J. Simko. 'The Balance Sheet as an Earnings Management Constraint.' The Accounting Review 77 (2002): 1-27.

Bartov, E., D. Givoly, and C. Hayn. 'The Rewards to Meeting or Beating Earnings Expectations.' Journal of Accounting and Economics 33 (2002): 173-204.

Berkman, H., V. Dimitrov, P. C. Jain, P. D. Koch, and S. Tice. 'Sell on the News: Differences of Opinion, Short-Sales Constraints, and Returns Around Earnings Announcements.' Journal of Financial Economics 92 (2009): 376-399.

Bissessur, S. W., and D. Veenman. 'Analyst Information Precision and Small Earnings Surprises.' Review of Accounting Studies 21 (2016): 1327-1360.

Bowen, R. M., A. K. Davis, and D. A. Matsumoto. 'Do Conference Calls Affect Analysts' Forecasts?' The Accounting Review 77 (2002): 285-316.

Brown, L. D. 'A Temporal Analysis of Earnings Surprises: Profits versus Losses.' Journal of Accounting Research 39 (2001): 221-241.

Chan, L. K. C., J. Karceski, and J. LAkonishok. 'Analysts' Conflicts of Interest and Biases in Earnings Forecasts.' Journal of Financial and Quantitative Analysis 42 (2007): 893-913.

Chang, T. Y., S. M. Hartzmark, D. H. Solomon, and E. F. Soltes. 'Being Surprised by the Unsurprising: Earnings Seasonality and Stock Returns.' The Review of Financial Studies 30 (2017): 281-323.

Chen, S., D. Matsumoto, and S. Rajgopal. 'Is Silence Golden? An Empirical Analysis of Firms That Stop Giving Quarterly Earnings Guidance.' Journal of Accounting and Economics 51 (2011): 134-150.

Cheong, F. S., and J. Thomas. 'Management of Reported and Forecast EPS, Investor Responses, and Research Implications.' Management Science 64 (2018): 4277-4301.

Chordia, T., A. Subrahmanyam, and Q. Tong. 'Have Capital Market Anomalies Attenuated in the Recent Era of High Liquidity and Trading Activity?' Journal of Accounting and Economics 58 (2014): $41-58$. 
Chuk, E., D. Matsumoto, and G. S. Miller. 'Assessing Methods of Identifying Management Forecasts: CIG vs. Researcher Collected.' Journal of Accounting and Economics 55 (2013): 23-42.

Ciconte, W., M. Kirk, and J. W. Tucker. 'Does the Midpoint of Range Earnings Forecasts Represent Managers' Expectations?' Review of Accounting Studies 19 (2014): 628-660.

Clement, M., R. Frankel, and J. Miller. 'Confirming Management Earnings Forecasts, Earnings Uncertainty, and Stock Returns.' Journal of Accounting Research 41 (2003): 653-679.

Conen, D. A., A. Dey, T. Z. Lys, and S. V. Sunder. 'Earnings Announcement Premia and the Limits to Arbitrage.' Journal of Accounting and Economics 43 (2007): 153-180.

Cotter, J., I. Tuna, and P. D. Wysocki. 'Expectations Management and Beatable Targets: How Do Analysts React to Explicit Earnings Guidance?' Contemporary Accounting Research 23 (2006): 593-624.

Dellavigna, S., and J. M. Pollet. 'Investor Inattention and Friday Earnings Announcements.' The Journal of Finance 64 (2009): 709-749.

Diether, K. B., C. J. Malloy, and A. Scherbina. 'Differences of Opinion and the Cross Section of Stock Returns.' The Journal of Finance 57 (2002): 2113-2141.

Doukas, J. A., C. F. Kim, and C. Pantzalis. 'Divergence of Opinion and Equity Returns.' Journal of Financial and Quantitative Analysis 41 (2006): 573-606.

Durtschi, C., and P. Easton. 'Earnings Management? The Shapes of the Frequency Distributions of Earnings Metrics Are Not Evidence Ipso Facto.' Journal of Accounting Research 43 (2005): 557-592.

Fama, E. F., and J. D. MacBeth. 'Risk, Return, and Equilibrium: Empirical Tests.' Journal of Political Economy 81 (1973): 607-36.

FEnG, M., and S. MCVAY. 'Analysts' Incentives to Overweight Management Guidance When Revising Their Short-Term Earnings Forecasts.' The Accounting Review 85 (2010): 1617-1646.

Gow, I. D., D. F. Larcker, and P. C. Reiss. 'Causal Inference in Accounting Research.' Journal of Accounting Research 54 (2016): 477-523.

Graham, J. R., C. R. Harvey, and S. Rajgopal. 'The Economic Implications of Corporate Financial Reporting.' Journal of Accounting and Economics 40 (2005): 3-73.

Green, J., J. R. M. Hand, and M. T. Soliman. 'Going, Going, Gone? The Apparent Demise of the Accruals Anomaly.' Management Science 57 (2011): 797-816.

Gryta, T., S. NG, and T. Francis. 'Companies Routinely Steer Analysts to Deliver Earnings Surprises.' Wall Street Journal (2016).

HaYn, C. 'The Information Content of Losses.' Journal of Accounting and Economics 20 (1995): 125-153.

Heflin, F., and C. Hsu. 'The Impact of the SEC's Regulation of Non-GAAP Disclosures.' Journal of Accounting and Economics 46 (2008): 349-365.

Hilary, G., and C. Hsu. 'Analyst Forecast Consistency.' The Journal of Finance 68 (2013): 271-297.

Hong, H., J. D. Kubik, and A. Solomon. 'Security Analysts' Career Concerns and Herding of Earnings Forecasts.' The RAND Journal of Economics 31 (2000): 121-144.

Houston, J. F., B. Lev, and J. W. Tucker. 'To Guide or Not to Guide? Causes and Consequences of Stopping Quarterly Earnings Guidance.' Contemporary Accounting Research 27 (2010): 143-185. 
Hutton, A. P. 'Determinants of Managerial Earnings Guidance Prior to Regulation Fair Disclosure and Bias in Analysts' Earnings Forecasts.' Contemporary Accounting Research 22 (2005): 867-914.

Hwang, C.-Y., and Y. LI. 'Analysts' Reputational Concerns, Self-Censoring, and the International Dispersion Effect.' Management Science 64 (2017): 2289-2307.

Irani, A. J., and I. Karamanou. 'Regulation Fair Disclosure, Analyst Following, and Analyst Forecast Dispersion.' Accounting Horizons 17 (2003): 15-29.

Jiang, J. X., K. R. Petroni, and I. Yanyan Wang. 'CFOs and CEOs: Who Have the Most Influence on Earnings Management?' Journal of Financial Economics 96 (2010): 513-526.

Johnson, T. C. 'Forecast Dispersion and the Cross Section of Expected Returns.' The Journal of Finance 59 (2004): 1957-1978.

Johnson, T. L., J. Kim, and E. C. So. 'Expectations Management and Stock Returns.' The Review of Financial Studies 33 (2020): 4580-4626.

Johnson, T. L., and E. C. So. 'Asymmetric Trading Costs Prior to Earnings Announcements: Implications for Price Discovery and Returns.' Journal of Accounting Research 56 (2018): 217-263.

Kasznik, R., and M. F. McNichols. 'Does Meeting Earnings Expectations Matter? Evidence from Analyst Forecast Revisions and Share Prices.' Journal of Accounting Research 40 (2002): 727-759.

Ke, B., and Y. Yu. 'The Effect of Issuing Biased Earnings Forecasts on Analysts' Access to Management and Survival.' Journal of Accounting Research 44 (2006): 965-999.

Keung, E., Z.-X. Lin, and M. Shin. 'Does the Stock Market See a Zero or Small Positive Earnings Surprise as a Red Flag?' Journal of Accounting Research 48 (2010): 91-121.

Levi, S., and X.-J. Zhang. 'Asymmetric Decrease in Liquidity Trading Before Earnings Announcements and the Announcement Return Premium.' Journal of Financial Economics 118 (2015): 383-398.

LiU, X. G., and R. NAtarajan. 'The Effect of Financial Analysts' Strategic Behavior on Analysts' Forecast Dispersion.' The Accounting Review 87 (2012): 2123-2149.

Livnat, J., and R. R. Mendenhall. 'Comparing the Post-Earnings Announcement Drift for Surprises Calculated from Analyst and Time Series Forecasts.' Journal of Accounting Research 44 (2006): 177-205.

Ma, G., and S. Markov. 'The Market's Assessment of the Probability of Meeting or Beating the Consensus.' Contemporary Accounting Research 34 (2017): 314-342.

Matsumoto, D. A. 'Management's Incentives to Avoid Negative Earnings Surprises.' The Accounting Review 77 (2002): 483-514.

McLean, R. D., and J. Pontiff. 'Does Academic Research Destroy Stock Return Predictability?' The Journal of Finance 71 (2016): 5-32.

McNichols, M., and P. C. O'Brien. 'Self-Selection and Analyst Coverage.' Journal of Accounting Research 35 (1997): 167-199.

Miller, E. M. 'Risk, Uncertainty, and Divergence of Opinion.' The Journal of Finance 32 (1977): 11511168.

Mohanram, P. S., and S. V. Sunder. 'How Has Regulation FD Affected the Operations of Financial Analysts?' Contemporary Accounting Research 23 (2006): 491-525. 
Morgan, S. L., and C. Winship. Counterfactuals and Causal Inference. 2nd edition. New York: Cambridge University Press, 2015.

NAGEL, S. 'Short Sales, Institutional Investors and the Cross-Section of Stock Returns.' Journal of Financial Economics 78 (2005): 277-309.

Newey, W. K., and K. D. West. 'A Simple, Positive Semi-Definite, Heteroskedasticity and Autocorrelation Consistent Covariance Matrix.' Econometrica 55 (1987): 703-708.

Pearl, J. 'Causal Diagrams for Empirical Research.' Biometrika 82 (1995): 669-688.

Richardson, S. A., S. H. Teoh, and P. D. Wysocki. 'The Walk-down to Beatable Analyst Forecasts: The Role of Equity Issuance and Insider Trading Incentives.' Contemporary Accounting Research 21 (2004): 885-924.

Sadka, R., and A. Scherbina. 'Analyst Disagreement, Mispricing, and Liquidity.' The Journal of Finance 62 (2007): 2367-2403.

Shumway, T., and V. A. Warther. 'The Delisting Bias in CRSP's Nasdaq Data and Its Implications for the Size Effect.' The Journal of Finance 54 (1999): 2361-2379.

So, E. C., and S. WANG. 'News-Driven Return Reversals: Liquidity Provision Ahead of Earnings Announcements.' Journal of Financial Economics 114 (2014): 20-35.

Trueman, B. 'Analyst Forecasts and Herding Behavior.' The Review of Financial Studies 7 (1994): 97-124.

Veenman, D., and P. Verwijmeren. 'Do Investors Fully Unravel Persistent Pessimism in Analysts' Earnings Forecasts?' The Accounting Review 93 (2018): 349-377.

WANG, I. Y. 'Private Earnings Guidance and Its Implications for Disclosure Regulation.' The Accounting Review 82 (2007): 1299-1332.

Zweig, J. 'Earnings Surprises: The Stock Market's Worst-Kept Secret.' Wall Street Journal (2018). 


\section{Figure 1}

Causal diagrams explaining the conceptual relations between the earnings expectations management game and analyst forecast dispersion

This figure provides causal diagrams using directed acyclic graphs (Pearl [1995]; Morgan and Winship [2015]; Gow et al. [2016]). Solid dots indicate observable constructs and hollow dots indicate unobservable constructs. The solid lines capture causal chains, while the dashed bidirected lines capture non-causal associations between constructs. Panel A depicts the within firm-quarter conceptual links between expectations management, forecast dispersion, and firm's propensity to meet or beat analyst expectations. See Section 2.1 for the argumentation and references behind these causal chains. Panel B depicts the conceptual links across quarters between persistent pessimism in analyst forecasts, forecast dispersion, and firm's propensity to meet or beat analyst expectations, which further strengthens the negative relation between dispersion and firms' propensity to meet or beat analyst expectations. See Section 2.2 for the argumentation and references behind these causal chains. Abbreviation EXM refers to expectations management, while $M B E$ refers to meeting or beating analyst expectations. Subscripts $t$ and $t-1$ refer to firm-quarters in event time.

Panel A: Within-quarter effect of expectations management on analyst dispersion

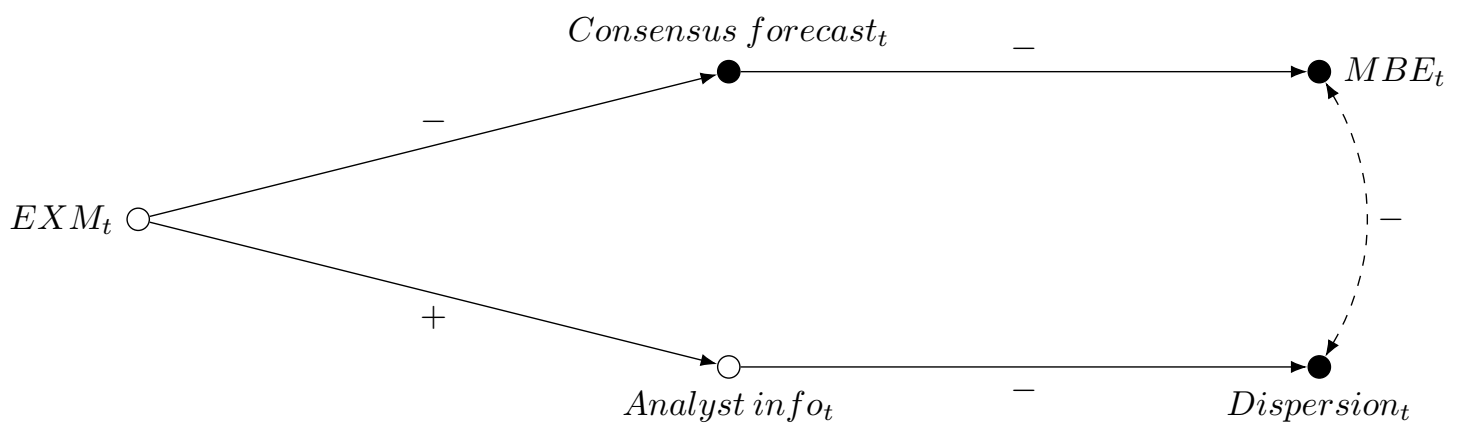

Panel B: Across-quarter effect of pessimistically biased earnings forecasts on analyst dispersion

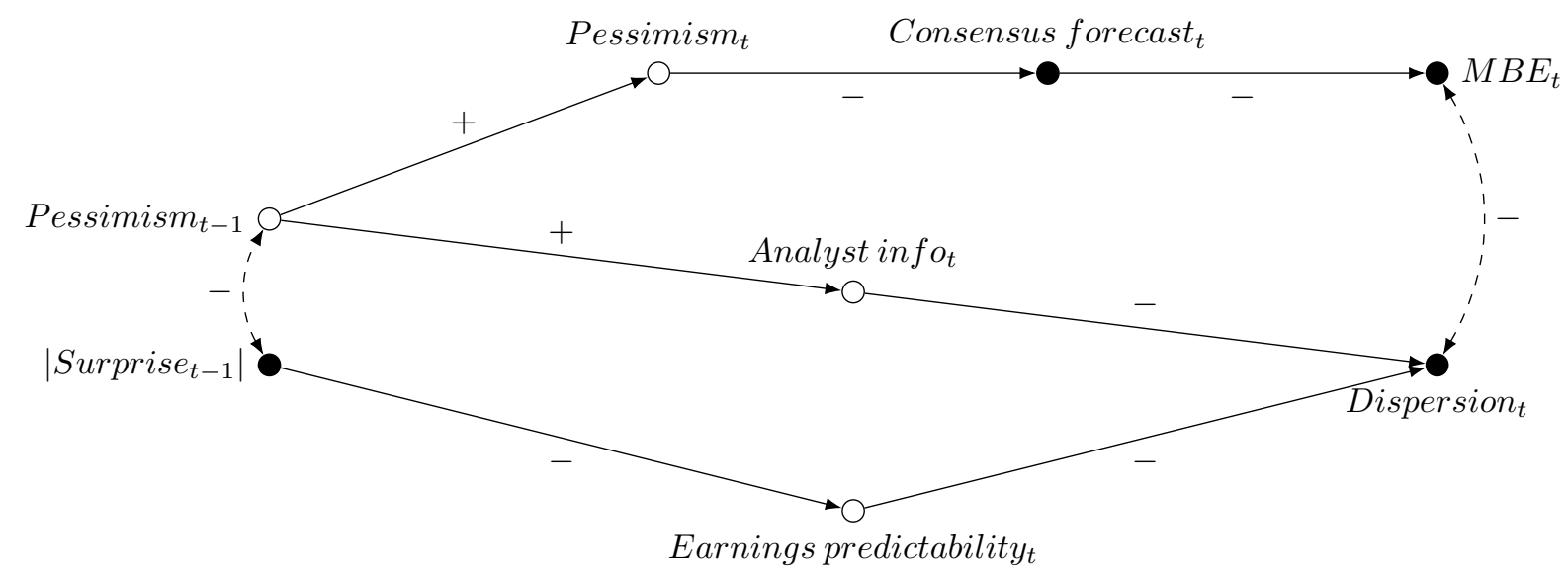




\section{Figure 2}

Frequency distribution of earnings surprises for low- and high-dispersion firms

Frequency distributions (kernel density plots) of quarterly earnings surprises (Surprise $_{t}$ ) for firms in the lowest quintile (Q1, solid red line) and firms in the highest quintile (Q5, dashed blue line) of analyst forecast dispersion. Analyst forecast dispersion is measured as the coefficient of variation in analysts' forecasts of annual earnings $\left(\operatorname{Disp} A_{t}\right)$ in the month before a quarterly earnings announcement. Quintile portfolios of forecast dispersion are created each quarter and kernel density plots are based on the Guassian kernel function and a bandwidth of one. See Appendix A for details on the definitions of variables Disp $A_{t}$ and Surprise $_{t}$ and Table 1 for sample selection details.

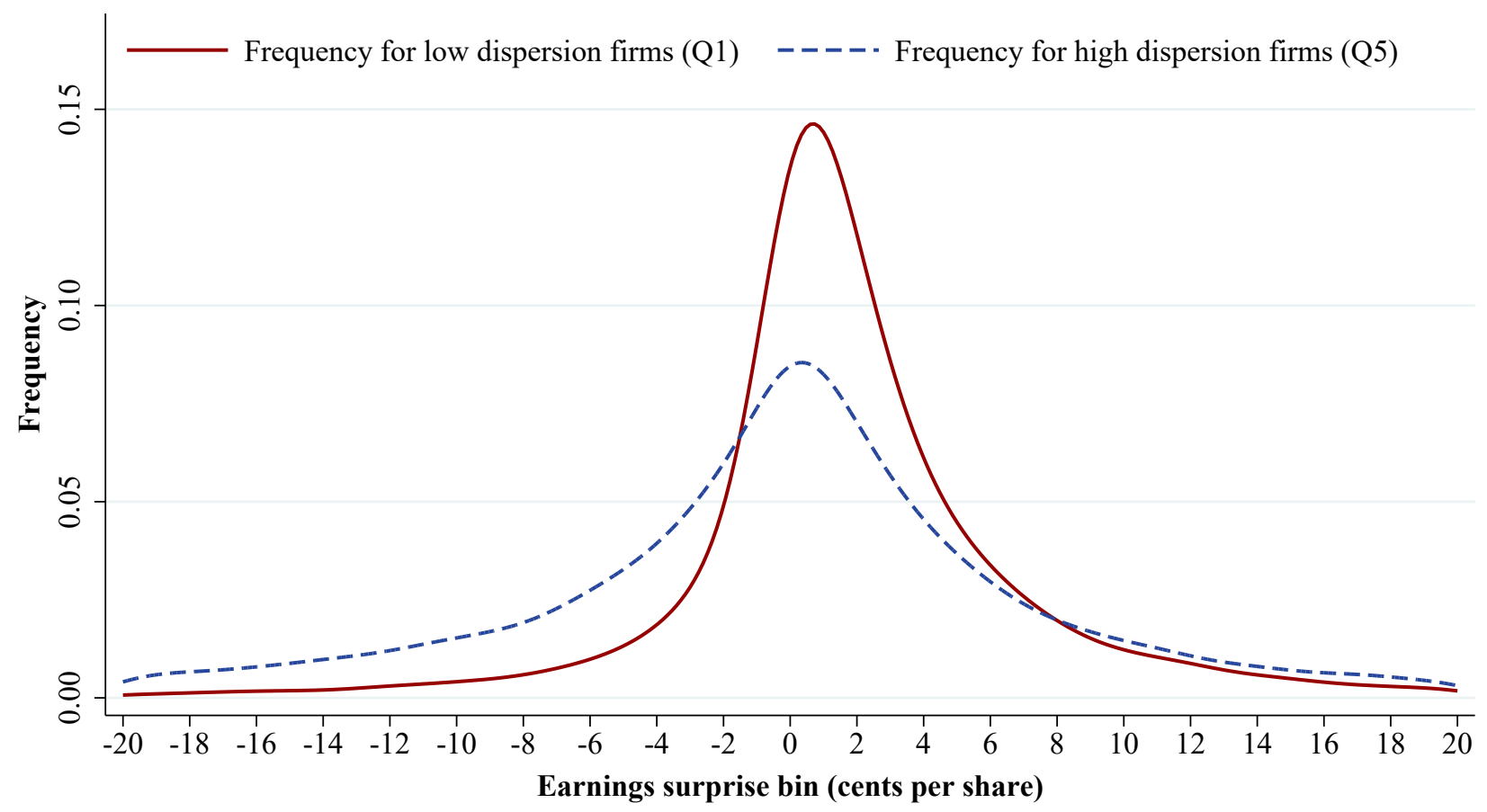




\section{Figure 3}

\section{The evolution of forecast dispersion within the quarter}

This figure presents insights on the evolution of forecast dispersion before firms' quarterly earnings announcements. We plot the level of forecast dispersion separately for firms that are more versus less likely engaged in the earnings expectations game. For each earnings announcement in our sample, we compute a consensus earnings forecast on day $\tau$ using a moving window that captures analysts' latest forecasts of quarterly earnings issued over the (maximum) 180 days before day $\tau$. Day $\tau$ forecast dispersion is measured as the standard deviation of the forecasts in the day $\tau$ consensus scaled by the absolute value of the consensus forecast on day -120 . For each day $\tau$, we plot the mean of the natural logarithm of forecast dispersion relative to the day -120 value, such that values on the vertical axis can be interpreted as the average percentage change in forecast dispersion within the quarter. To capture firms' potential involvement in the earnings expectations game, the left-hand figure displays the evolution of forecast dispersion separately for firms identified as providing guidance, versus those that do not, using the IBES Guidance data for the post-1998 part of our sample (Chuk et al. [2013]). The right-hand figure plots the evolution of forecast dispersion separately for firms with high versus low frequencies of meeting or beating consensus expectations (MBE) in the previous 12 quarters (using a minimum of four previous earnings surprises). Firms are labeled as having a high (low) MBE frequency when the fraction of quarters meeting or beating consensus expectations exceeds (is smaller than or equal to) 2/3. See Table 1 for sample selection details.
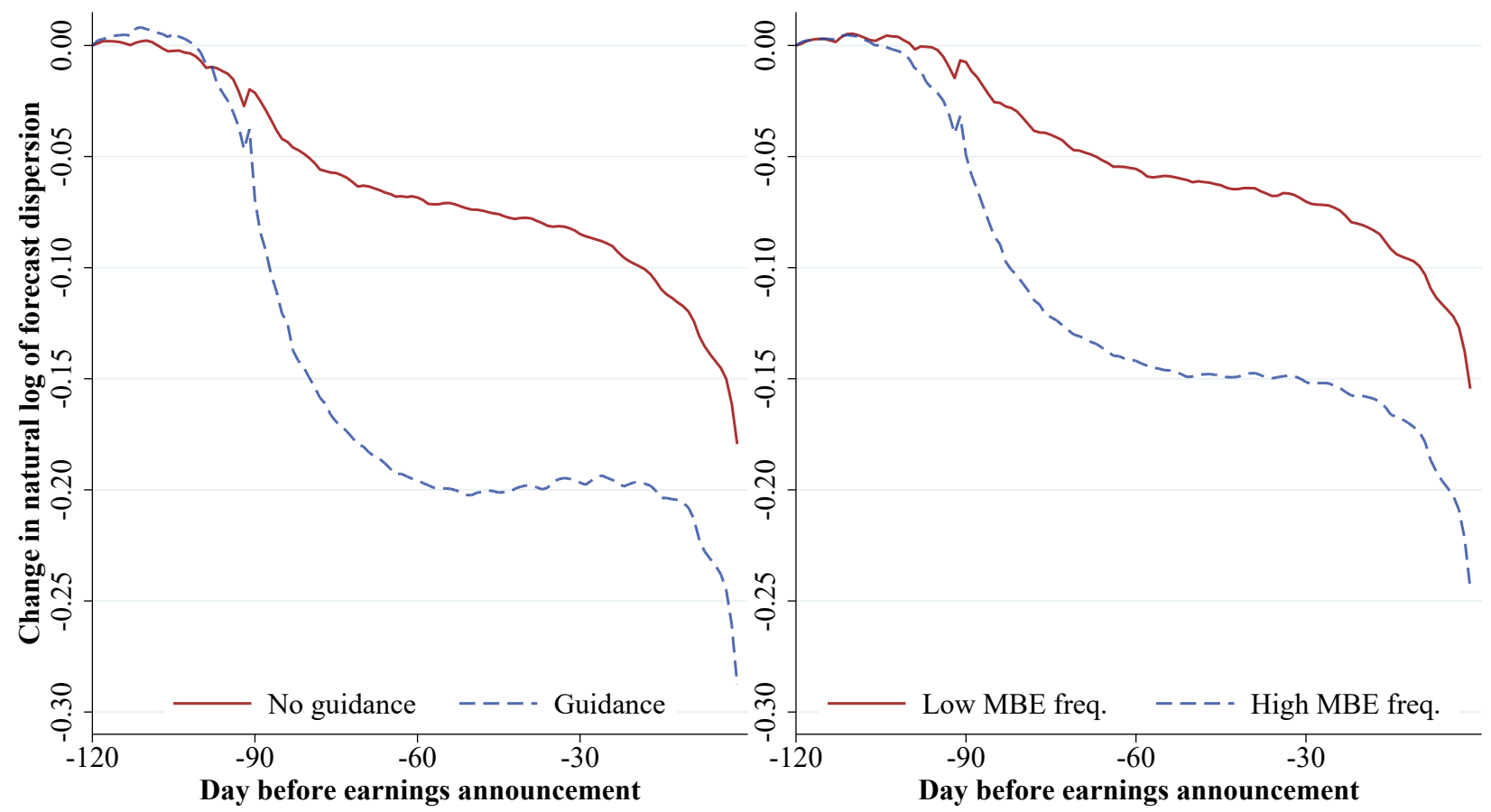
Table 1

Sample selection and descriptive statistics

\begin{tabular}{lr}
\hline Construction of monthly return dataset & Security-months \\
\hline Observations with return data in CRSP for months 1993:04-2019:03 & $2,292,363$ \\
- Not listed on NYSE, AMEX, or NASDAQ & $-155,440$ \\
- Add delisting return months & 13,567 \\
- Stock price below \$1 at end of previous month & $-77,104$ \\
- Dispersion variables not available in previous month & $-1,102,173$ \\
Sample for basic dispersion anomaly tests (Table 2) & 971,213 \\
- Expected earnings announcement months (Table 2) & 295,606 \\
- Sample with basic controls and PESS and EMI measures (Tables 3-5) & 277,690 \\
& \\
Construction of earnings announcement dataset & Firm-quarters \\
\hline Unique firm-quarters in CRSP/Compustat for fiscal periods ending in calendar quar- & 604,487 \\
ters 1993Q1 through 2018Q4 with positive total assets and non-missing net income & \\
(IBQ), stock price (PRCCQ), and shares outstanding (CSHOQ) & $-4,617$ \\
- Firm not listed on NYSE, AMEX, or NASDAQ & $-24,857$ \\
- Stock price below \$1 at fiscal quarter end & $-43,761$ \\
- Missing earnings announcement date in Compustat & $-163,036$ \\
- Missing earnings surprise data in IBES & $-6,753$ \\
- Earnings announcement dates differ by > 2 trading days & $-7,823$ \\
- Earnings announcement return data not available in CRSP & $-58,217$ \\
- Dispersion variables not available in month before earnings announcement & $-4,649$ \\
- Data on control variables missing & 290,774 \\
Sample with dispersion variables and earnings announcement data (Tables 6-7) &
\end{tabular}

Notes: This table presents the procedures used to construct (1) a sample of firm-month observations for tests of the dispersion anomaly and (2) a sample of firm-quarters for tests of earnings announcement news. The firm-month sample covers the 312 months from April 1993 through March 2019 to match the selection of firm-quarters ending in calendar quarters 1993Q1-2018Q4. Expected earnings announcement months are defined based on quarterly earnings announcements made in the same month one year earlier. See Appendix A for variable definitions. 


\section{Table 2}

Analyst forecast dispersion, stock returns, and earnings announcements

Panel A: Average returns by monthly dispersion quintile based on annual earnings forecasts

\begin{tabular}{|c|c|c|c|c|c|c|c|}
\hline & \multicolumn{5}{|c|}{ Dispersion portfolio } & \multirow[b]{2}{*}{ Q1-Q5 } & \multirow{2}{*}{$\begin{array}{c}\text { EA vs. } \\
\text { non-EA } \\
\text { diff. }\end{array}$} \\
\hline & Q1 (low) & Q2 & Q3 & Q4 & Q5 (high) & & \\
\hline \multirow[t]{2}{*}{ All } & 0.908 & 0.839 & 0.781 & 0.661 & 0.477 & 0.430 & \\
\hline & $(3.55)^{* * *}$ & $(2.91)^{* * *}$ & $(2.35)^{* *}$ & $(1.69)^{*}$ & $(1.02)$ & $(1.52)$ & \\
\hline \multirow[t]{2}{*}{ All (alphas) } & 0.252 & 0.140 & 0.057 & -0.107 & -0.302 & 0.554 & \\
\hline & $(3.10)^{* * *}$ & $(1.99)^{* *}$ & $(1.01)$ & $(-1.27)$ & $(-2.47)^{* *}$ & $(3.34)^{* * *}$ & \\
\hline \multirow[t]{2}{*}{$\mathrm{EA}(\exp )$} & 1.350 & 1.207 & 0.985 & 0.887 & 0.701 & 0.649 & \\
\hline & $(5.04)^{* * *}$ & $(3.99)^{* * *}$ & $(2.80)^{* * *}$ & $(2.15)^{* *}$ & $(1.46)$ & $(2.15)^{* *}$ & \\
\hline \multirow[t]{2}{*}{ Non-EA (exp) } & 0.721 & 0.686 & 0.685 & 0.630 & 0.484 & 0.237 & 0.413 \\
\hline & $(2.67)^{* * *}$ & $(2.37)^{* *}$ & $(2.10)^{* *}$ & $(1.63)$ & $(1.05)$ & $(0.81)$ & $(2.06)^{* *}$ \\
\hline \multirow[t]{2}{*}{$\mathrm{EA}$ (act) } & 1.382 & 1.194 & 0.934 & 0.980 & 0.638 & 0.744 & \\
\hline & $(5.01)^{* * *}$ & $(3.77)^{* * *}$ & $(2.60)^{* * *}$ & $(2.30)^{* *}$ & $(1.28)$ & $(2.37)^{* *}$ & \\
\hline \multirow[t]{2}{*}{ Non-EA (act) } & 0.672 & 0.633 & 0.620 & 0.565 & 0.454 & 0.218 & 0.525 \\
\hline & $(2.47)^{* *}$ & $(2.14)^{* *}$ & $(1.86)^{*}$ & $(1.44)$ & $(0.98)$ & $(0.75)$ & $(2.66)^{* * *}$ \\
\hline \multirow[t]{2}{*}{$B H A R_{t}^{[0,2]}$} & 0.246 & 0.115 & -0.170 & -0.205 & -0.366 & 0.612 & \\
\hline & $(4.73)^{* * *}$ & $(1.76)^{*}$ & $(-2.63) * * *$ & $(-2.81)^{* * *}$ & $(-3.39)^{* * *}$ & $(4.93)^{* * *}$ & \\
\hline \multirow[t]{2}{*}{$\operatorname{Ret} X_{t}^{[0,2]}$} & 1.266 & 1.297 & 1.277 & 1.408 & 1.280 & -0.014 & \\
\hline & $(5.33)^{* * *}$ & $(4.87)^{* * *}$ & $(4.31)^{* * *}$ & $(3.96)^{* * *}$ & $(3.06)^{* * *}$ & $(-0.05)$ & \\
\hline
\end{tabular}

Panel B: Average returns by monthly dispersion quintile based on quarterly earnings forecasts

\begin{tabular}{|c|c|c|c|c|c|c|c|}
\hline & \multicolumn{5}{|c|}{ Dispersion portfolio } & \multirow[b]{2}{*}{ Q1-Q5 } & \multirow{2}{*}{$\begin{array}{c}\text { EA vs. } \\
\text { non-EA } \\
\text { diff. }\end{array}$} \\
\hline & Q1 (low) & Q2 & Q3 & Q4 & Q5 (high) & & \\
\hline \multirow[t]{2}{*}{ All } & 0.903 & 0.859 & 0.738 & 0.682 & 0.479 & 0.425 & \\
\hline & $(3.20)^{* * *}$ & $(3.02)^{* * *}$ & $(2.25)^{* *}$ & $(1.75)^{*}$ & $(1.09)$ & $(2.10)^{* *}$ & \\
\hline \multirow[t]{2}{*}{ All (alphas) } & 0.205 & 0.175 & 0.027 & -0.065 & -0.310 & 0.515 & \\
\hline & $(2.85)^{* * *}$ & $(2.54)^{* *}$ & $(0.48)$ & $(-0.74)$ & $(-2.87) * * *$ & $(3.98) * * *$ & \\
\hline \multirow[t]{2}{*}{ EA (exp) } & 1.187 & 1.350 & 1.150 & 0.922 & 0.586 & 0.601 & \\
\hline & $(3.83)^{* * *}$ & $(4.60)^{* * *}$ & $(3.44)^{* * *}$ & $(2.17)^{* *}$ & $(1.31)$ & $(2.74)^{* * *}$ & \\
\hline \multirow[t]{2}{*}{ Non-EA (exp) } & 0.806 & 0.664 & 0.606 & 0.652 & 0.509 & 0.297 & 0.304 \\
\hline & $(2.85)^{* * *}$ & $(2.30)^{* *}$ & $(1.87)^{*}$ & $(1.72)^{*}$ & $(1.17)$ & $(1.38)$ & $(1.68)^{*}$ \\
\hline \multirow[t]{2}{*}{ EA (act) } & 1.281 & 1.342 & 1.178 & 0.861 & 0.541 & 0.740 & \\
\hline & $(4.06)^{* * *}$ & $(4.32)^{* * *}$ & $(3.38)^{* * *}$ & $(2.03)^{* *}$ & $(1.18)$ & $(3.54)^{* * *}$ & \\
\hline \multirow[t]{2}{*}{ Non-EA (act) } & 0.741 & 0.589 & 0.533 & 0.592 & 0.504 & 0.237 & 0.503 \\
\hline & $(2.58) * *$ & $(2.01)^{* *}$ & $(1.61)$ & $(1.53)$ & $(1.15)$ & (1.12) & $(3.15)^{* * *}$ \\
\hline \multirow[t]{2}{*}{$B H A R_{t}^{[0,2]}$} & 0.138 & 0.144 & -0.010 & -0.218 & -0.388 & 0.526 & \\
\hline & $(2.46)^{* *}$ & $(2.37)^{* *}$ & $(-0.14)$ & $(-2.74)^{* * *}$ & $(-3.91) * * *$ & $(4.73)^{* * *}$ & \\
\hline \multirow[t]{2}{*}{$\operatorname{Ret} X_{t}^{[0,2]}$} & 1.263 & 1.337 & 1.370 & 1.352 & 1.260 & 0.004 & \\
\hline & $(4.79)^{* * *}$ & $(5.17)^{* * *}$ & $(4.49)^{* * *}$ & $(3.89) * * *$ & $(3.29) * * *$ & $(0.02)$ & \\
\hline
\end{tabular}


Notes: This table presents time-series averages of monthly stock returns $\left(\operatorname{Ret}_{t}\right)$ for quintile portfolios formed based on forecast dispersion. The sample consists of security-month observations for the 312 months from April 1993 through March 2019. CRSP delisting returns are included and adjusted for missing values following Shumway and Warther [1999]. See Table 1 for sample selection details. Forecast dispersion is measured from the IBES Summary History files using forecasts of annual earnings (Disp $A_{t}$, Panel A) and forecasts of quarterly earnings (Disp $Q_{t}$, Panel B) in the previous month. Quintile portfolios are constructed for each of the 312 months in the sample using the previous-month ranks of the dispersion variable. Alphas are calculated as the intercept from Fama-French four-factor model regressions. EA (non-EA) refers to security-months with (without) an earnings announcement. We distinguish between expected "(exp)" and actual "(act)" earnings announcement months, where expected earnings announcement months are extrapolated from the same-quarter earnings announcement one year earlier and earnings announcement dates are from Compustat (RDQ). The earnings announcement return variables $B H A R_{t}^{[0,2]}$ and $R E T X_{t}^{[0,2]}$ are measured relative to the earnings announcement date as identified in Table 1. See Appendix A for details on the forecast dispersion and return variable definitions. Average return values are multiplied by 100 for presentation purposes. $t$-statistics are based on time series averages and standard errors adjusted for autocorrelation using Newey and West [1987] and five lags. ${ }^{*},{ }^{* *}$, and ${ }^{* * *}$ represent statistical significance at the $0.10,0.05$, and 0.01 level, respectively. 
Table 3

Cross-sectional regressions explaining returns in expected announcement months

\begin{tabular}{|c|c|c|c|c|c|c|}
\hline & Ret $_{t}$ & $\operatorname{Ret}_{t}$ & $\operatorname{Ret}_{t}$ & $\operatorname{Ret}_{t}$ & $\operatorname{Ret}_{t}$ & Ret $_{t}$ \\
\hline \multicolumn{7}{|l|}{ Test variables: } \\
\hline $\operatorname{Disp} A_{t-1}$ & $\begin{array}{c}-0.607 \\
(-2.72)^{* * *}\end{array}$ & $\begin{array}{c}-0.608 \\
(-3.81)^{* * *}\end{array}$ & $\begin{array}{l}-0.273 \\
(-1.26)\end{array}$ & & & \\
\hline $\operatorname{Disp} Q_{t-1}$ & & & & $\begin{array}{c}-0.620 \\
(-3.38)^{* * *}\end{array}$ & $\begin{array}{c}-0.580 \\
(-3.59)^{* * *}\end{array}$ & $\begin{array}{c}-0.293 \\
(-1.67)^{*}\end{array}$ \\
\hline \multicolumn{7}{|l|}{ Control variables: } \\
\hline Size $_{t-1}$ & $\begin{array}{l}-0.006 \\
(-0.02)\end{array}$ & $\begin{array}{c}-0.717 \\
(-1.89)^{*}\end{array}$ & $\begin{array}{c}-0.568 \\
(-1.70)^{*}\end{array}$ & $\begin{array}{l}-0.013 \\
(-0.04)\end{array}$ & $\begin{array}{c}-0.749 \\
(-1.96)^{*}\end{array}$ & $\begin{array}{c}-0.568 \\
(-1.66)^{*}\end{array}$ \\
\hline$B t M_{t-1}$ & $\begin{array}{c}0.755 \\
(2.29)^{* *}\end{array}$ & $\begin{array}{c}0.792 \\
(3.39)^{* * *}\end{array}$ & $\begin{array}{c}0.619 \\
(2.16)^{* *}\end{array}$ & $\begin{array}{c}0.774 \\
(2.33)^{* *}\end{array}$ & $\begin{array}{c}0.817 \\
(3.47)^{* * *}\end{array}$ & $\begin{array}{c}0.649 \\
(2.24)^{* *}\end{array}$ \\
\hline $\operatorname{Ret}_{t-1}$ & $\begin{array}{c}-0.887 \\
(-3.27)^{* * *}\end{array}$ & $\begin{array}{c}-0.963 \\
(-3.74)^{* * *}\end{array}$ & $\begin{array}{c}-0.894 \\
(-3.30)^{* * *}\end{array}$ & $\begin{array}{c}-0.866 \\
(-3.19)^{* * *}\end{array}$ & $\begin{array}{c}-0.938 \\
(-3.67)^{* * *}\end{array}$ & $\begin{array}{c}-0.877 \\
(-3.25)^{* * *}\end{array}$ \\
\hline $\operatorname{Ret}_{t-12, t-2}$ & $\begin{array}{c}1.113 \\
(2.48)^{* *}\end{array}$ & $\begin{array}{c}1.233 \\
(3.07)^{* * *}\end{array}$ & $\begin{array}{c}1.157 \\
(2.60)^{* * *}\end{array}$ & $\begin{array}{c}1.139 \\
(2.47)^{* *}\end{array}$ & $\begin{array}{c}1.272 \\
(3.17)^{* * *}\end{array}$ & $\begin{array}{c}1.178 \\
(2.57)^{* *}\end{array}$ \\
\hline $\operatorname{Lev}_{t-1}$ & & $\begin{array}{c}-0.434 \\
(-1.94)^{*}\end{array}$ & & & $\begin{array}{l}-0.403 \\
(-1.79)^{*}\end{array}$ & \\
\hline$A g e_{t-1}$ & & $\begin{array}{l}0.171 \\
(1.02)\end{array}$ & & & $\begin{array}{l}0.193 \\
(1.14)\end{array}$ & \\
\hline Analysts $_{t-1}$ & & $\begin{array}{c}0.607 \\
(2.31)^{* *}\end{array}$ & & & $\begin{array}{c}0.665 \\
(2.58)^{* *}\end{array}$ & \\
\hline Inst $_{t-1}$ & & $\begin{array}{l}-0.341 \\
(-1.55)\end{array}$ & & & $\begin{array}{c}-0.371 \\
(-1.73)^{*}\end{array}$ & \\
\hline Retvol $_{t-1}$ & & $\begin{array}{l}-0.459 \\
(-1.52)\end{array}$ & & & $\begin{array}{l}-0.487 \\
(-1.58)\end{array}$ & \\
\hline Evol $_{t-1}$ & & $\begin{array}{l}-0.015 \\
(-0.06)\end{array}$ & & & $\begin{array}{l}-0.057 \\
(-0.22)\end{array}$ & \\
\hline Turn $_{t-1}$ & & $\begin{array}{l}0.361 \\
(1.27)\end{array}$ & & & $\begin{array}{c}0.332 \\
(1.20)\end{array}$ & \\
\hline$E M I_{t-1}$ & & & $\begin{array}{c}0.825 \\
(2.75)^{* * *}\end{array}$ & & & $\begin{array}{c}0.825 \\
(2.66)^{* * *}\end{array}$ \\
\hline$P E S S_{t-1}^{C}$ & & & $\begin{array}{c}0.262 \\
(2.00)^{* *}\end{array}$ & & & $\begin{array}{c}0.287 \\
(2.14)^{* *}\end{array}$ \\
\hline$P E S S_{t-1}^{I}$ & & & $\begin{array}{c}0.569 \\
(2.66)^{* * *}\end{array}$ & & & $\begin{array}{c}0.560 \\
(2.69)^{* * *}\end{array}$ \\
\hline $\mathrm{n}$ & 277,690 & 272,089 & 277,690 & 277,690 & 272,089 & 277,690 \\
\hline n (months) & 312 & 312 & 312 & 312 & 312 & 312 \\
\hline Average adj. $R^{2}$ & 0.042 & 0.062 & 0.048 & 0.040 & 0.062 & 0.047 \\
\hline
\end{tabular}

Notes: This table presents average coefficient estimates obtained from monthly cross-sectional regressions of returns on forecast dispersion and control variables in expected earnings announcement months. Average coefficients are multiplied by 100 for presentation purposes. All independent variables are transformed into monthly decile ranks, scaled between -0.5 and 0.5. See Appendix A for details on the variable definitions. $t$-statistics are based on time series averages and standard errors adjusted for autocorrelation using Newey and West [1987] and five lags. ${ }^{*},{ }^{* *}$, and ${ }^{* * *}$ represent statistical significance at the $0.10,0.05$, and 0.01 level, respectively. 


\section{Table 4}

Explaining forecast dispersion with ex-ante measures of expectations management incentives and forecast pessimism

Panel A: Descriptive for portfolios formed on expectations management incentives and forecast pessimism

\begin{tabular}{|c|c|c|c|c|c|c|c|}
\hline & \multicolumn{5}{|c|}{$E M I_{t-1}$ portfolio } & \multirow[b]{2}{*}{$\mathrm{Q} 5-\mathrm{Q} 1$} & \multirow[b]{2}{*}{$t$-stat. } \\
\hline & Q1 (low) & Q2 & Q3 & Q4 & Q5 (high) & & \\
\hline Meet $_{t}$ & 0.598 & 0.630 & 0.669 & 0.695 & 0.741 & 0.143 & $16.78^{* * *}$ \\
\hline $\operatorname{Ret}_{t}$ & 0.636 & 1.361 & 1.483 & 1.519 & 1.523 & 0.887 & $3.34^{* * *}$ \\
\hline $\operatorname{Disp} A_{t-1}$ & 0.078 & 0.057 & 0.043 & 0.032 & 0.024 & -0.054 & $-18.60 * * *$ \\
\hline \multirow[t]{2}{*}{$\operatorname{Disp} Q_{t-1}$} & 0.130 & 0.102 & 0.082 & 0.063 & 0.044 & -0.086 & $-19.20 * * *$ \\
\hline & \multicolumn{5}{|c|}{$P E S S_{t-1}^{C}$ portfolio } & & \\
\hline Meet $_{t}$ & 0.510 & 0.604 & 0.672 & 0.739 & 0.836 & 0.326 & $46.13^{* * *}$ \\
\hline $\operatorname{Ret}_{t}$ & 0.649 & 1.095 & 1.229 & 1.137 & 1.445 & 0.797 & $4.35^{* * *}$ \\
\hline $\operatorname{Disp} A_{t-1}$ & 0.084 & 0.058 & 0.040 & 0.030 & 0.021 & -0.063 & $-19.73 * * *$ \\
\hline \multirow[t]{2}{*}{$D i s p Q_{t-1}$} & 0.142 & 0.104 & 0.076 & 0.058 & 0.042 & -0.100 & $-18.17 * * *$ \\
\hline & \multicolumn{5}{|c|}{$P E S S_{t-1}^{I}$ portfolio } & & \\
\hline Meet $_{t}$ & 0.531 & 0.613 & 0.668 & 0.728 & 0.794 & 0.262 & $30.14^{* * *}$ \\
\hline $\operatorname{Ret}_{t}$ & 0.662 & 0.971 & 1.042 & 1.386 & 1.473 & 0.811 & $3.96^{* * *}$ \\
\hline $\operatorname{Disp}_{t-1}$ & 0.073 & 0.050 & 0.039 & 0.032 & 0.027 & -0.045 & $-13.46^{* * *}$ \\
\hline $\operatorname{Disp} Q_{t-1}$ & 0.127 & 0.093 & 0.076 & 0.062 & 0.049 & -0.078 & $-14.65^{* * *}$ \\
\hline
\end{tabular}

Panel B: Cross-sectional regressions explaining variation in dispersion with ex-ante measures

\begin{tabular}{|c|c|c|c|c|c|c|}
\hline & $\ln \left(\operatorname{Disp}_{t-1}\right)$ & $\ln \left(\operatorname{Disp}_{t-1}\right)$ & $\ln \left(D i s p A_{t-1}\right)$ & $\ln \left(\operatorname{Disp} Q_{t-1}\right)$ & $\ln \left(\operatorname{Disp} Q_{t-1}\right)$ & $\ln \left(\operatorname{Disp} Q_{t-1}\right)$ \\
\hline \multirow[t]{2}{*}{$E M I_{t-1}$} & -0.393 & & -0.262 & -0.310 & & -0.171 \\
\hline & $(-29.92)^{* * *}$ & & $(-18.81)^{* * *}$ & $(-28.16) * * *$ & & $(-15.19) * * *$ \\
\hline \multirow{2}{*}{$P E S S_{t-1}^{C}$} & & -1.670 & -1.438 & & -1.524 & -1.366 \\
\hline & & $(-41.12)^{* * *}$ & $(-41.81) * * *$ & & $(-32.08)^{* * *}$ & $(-31.04) * * *$ \\
\hline \multirow[t]{2}{*}{$P E S S_{t-1}^{I}$} & & -1.317 & -1.062 & & -1.811 & -1.656 \\
\hline & & $(-11.69)^{* * *}$ & $(-9.84)^{* * *}$ & & $(-21.44) * * *$ & $(-20.45)^{* * *}$ \\
\hline $\mathrm{n}$ & 277,690 & 277,690 & 277,690 & 277,690 & 277,690 & 277,690 \\
\hline n (months) & 312 & 312 & 312 & 312 & 312 & 312 \\
\hline Avg. adj. $R^{2}$ & 0.072 & 0.115 & 0.147 & 0.035 & 0.083 & 0.094 \\
\hline
\end{tabular}

Panel C: Return predictability of fitted and residual components of dispersion

\begin{tabular}{|c|c|c|c|c|c|c|}
\hline & \multicolumn{3}{|c|}{$\operatorname{Disp}_{t-1}=\ln \left(\operatorname{Disp}_{t-1}\right)$} & \multicolumn{3}{|c|}{$\operatorname{Disp}_{t-1}=\ln \left(\operatorname{Disp}_{t-1}\right)$} \\
\hline & $\operatorname{Ret}_{t}$ & $\operatorname{Ret}_{t}$ & $\operatorname{Ret}_{t}$ & $\operatorname{Ret}_{t}$ & $\operatorname{Ret}_{t}$ & $\operatorname{Ret}_{t}$ \\
\hline \multicolumn{7}{|l|}{ Test variables: } \\
\hline$\overline{\text { Fitted Disp }} p_{t-1}$ & $\begin{array}{c}-1.221 \\
(-5.98)^{* * *}\end{array}$ & & $\begin{array}{c}-1.233 \\
(-5.92)^{* * *}\end{array}$ & $\begin{array}{c}-1.123 \\
(-6.01)^{* * *}\end{array}$ & & $\begin{array}{c}-1.140 \\
(-6.03)^{* * *}\end{array}$ \\
\hline Residual Disp ${ }_{t-1}$ & & $\begin{array}{l}-0.093 \\
(-0.49)\end{array}$ & $\begin{array}{l}-0.160 \\
(-0.82)\end{array}$ & & $\begin{array}{l}-0.135 \\
(-0.82)\end{array}$ & $\begin{array}{l}-0.207 \\
(-1.23)\end{array}$ \\
\hline$p$-value difference & & & [0.0002] & & & {$[0.0003]$} \\
\hline Control variables & Included & Included & Included & Included & Included & Included \\
\hline $\mathrm{n}$ & 277,690 & 277,690 & 277,690 & 277,690 & 277,690 & 277,690 \\
\hline $\mathrm{n}$ (months) & 312 & 312 & 312 & 312 & 312 & 312 \\
\hline Average adj. $R^{2}$ & 0.041 & 0.041 & 0.044 & 0.041 & 0.039 & 0.043 \\
\hline
\end{tabular}


Notes: Panel A presents time-series averages of variables Meet $_{t}, \operatorname{Ret}_{t}, \operatorname{Disp}_{t-1}$, and DispQ $Q_{t-1}$, for monthly quintile portfolios formed on variables $E M I_{t-1}, P E S S_{t-1}^{C}$, and $P E S S_{t-1}^{I}$. Panel B presents average coefficient estimates obtained from monthly cross-sectional regressions of the natural logarithm of forecast dispersion on $E M I_{t-1}, P E S S_{t-1}^{C}$, and $P E S S_{t-1}^{I}$. Panel C presents average coefficient estimates obtained from monthly cross-sectional regressions of returns on fitted and residual forecast dispersion and control variables $\left(S i z e_{t-1}, B t M_{t-1}, \operatorname{Ret}_{t-1}\right.$, and $\left.\operatorname{Ret}_{t-12, t-2}\right)$, where fitted and residual forecast dispersion are obtained from the first-stage estimations in Panel B including $E M I_{t-1}, P E S S_{t-1}^{C}$, and $P E S S_{t-1}^{I}$. In Panel C, average coefficients are multiplied by 100 for presentation purposes and independent variables (including untabulated control variables) are transformed into monthly decile ranks, scaled between -0.5 and 0.5. See Appendix A for the variable definitions. $t$-statistics are based on time series averages and standard errors adjusted for autocorrelation using Newey and West [1987] and five lags. *, **, and *** represent statistical significance at the $0.10,0.05$, and 0.01 level, respectively. 


\section{Table 5}

\section{Portfolio regression tests based on fitted and residual dispersion variables}

Panel A: Monthly portfolios formed on fitted and residual annual dispersion

\begin{tabular}{|c|c|c|c|c|c|c|c|}
\hline & \multicolumn{3}{|c|}{ Fitted $\ln \left(D i s p A_{t}\right)$} & \multicolumn{3}{|c|}{ Residual $\ln \left(\operatorname{Disp} A_{t}\right)$} & \multirow{2}{*}{$\begin{array}{l}\text { Fitted - } \\
\text { Residual }\end{array}$} \\
\hline & Q1 & Q5 & Q1-Q5 & Q1 & Q5 & Q1-Q5 & \\
\hline \multirow[t]{2}{*}{ Alpha } & 0.568 & -0.376 & 0.944 & 0.318 & 0.154 & 0.164 & 0.781 \\
\hline & $(4.73)^{* * *}$ & $(-2.38)^{* *}$ & $(4.81)^{* * *}$ & $(3.20)^{* * *}$ & $(0.92)$ & $(0.98)$ & $(3.16)^{* * *}$ \\
\hline \multirow[t]{2}{*}{$M K T R F$} & 1.054 & 1.108 & -0.054 & 0.915 & 1.221 & -0.306 & 0.253 \\
\hline & $(25.49)^{* * *}$ & $(24.73)^{* * *}$ & $(-0.80)$ & $(30.31)^{* * *}$ & $(35.57)^{* * *}$ & $(-6.84)^{* * *}$ & $(3.03)^{* * *}$ \\
\hline \multirow[t]{2}{*}{$S M B$} & 0.339 & 0.958 & -0.620 & 0.530 & 0.982 & -0.452 & -0.168 \\
\hline & $(2.43)^{* *}$ & $(16.83)^{* * *}$ & $(-3.56) * * *$ & $(8.21)^{* * *}$ & $(17.12)^{* * *}$ & $(-7.43)^{* * *}$ & $(-1.05)$ \\
\hline \multirow{2}{*}{$H M L$} & 0.209 & 0.209 & -0.000 & 0.299 & 0.221 & 0.079 & -0.079 \\
\hline & $(2.46)^{* *}$ & $(2.36)^{* *}$ & $(-0.00)$ & $(6.05)^{* * *}$ & $(4.19)^{* * *}$ & (1.19) & $(-0.52)$ \\
\hline \multirow[t]{2}{*}{$U M D$} & -0.097 & -0.222 & 0.125 & -0.029 & -0.392 & 0.363 & -0.238 \\
\hline & $(-2.14)^{* *}$ & $(-6.53)^{* * *}$ & $(1.80)^{*}$ & $(-0.95)$ & $(-10.92)^{* * *}$ & $(6.72)^{* * *}$ & $(-2.92)^{* * *}$ \\
\hline \multirow[t]{2}{*}{$E A R F$} & 0.177 & 0.016 & 0.161 & 0.188 & 0.023 & 0.165 & -0.003 \\
\hline & $(2.30)^{* *}$ & $(0.14)$ & $(1.24)$ & $(3.09)^{* * *}$ & $(0.28)$ & $(1.65)$ & $(-0.02)$ \\
\hline
\end{tabular}

Panel B: Monthly portfolios formed on fitted and residual quarterly dispersion

\begin{tabular}{|c|c|c|c|c|c|c|c|}
\hline & \multicolumn{3}{|c|}{ Fitted $\ln \left(D i s p Q_{t}\right)$} & \multicolumn{3}{|c|}{ Residual $\ln \left(\operatorname{Disp} Q_{t}\right)$} & \multirow{2}{*}{$\begin{array}{l}\text { Fitted - } \\
\text { Residual }\end{array}$} \\
\hline & Q1 & Q5 & Q1-Q5 & Q1 & Q5 & Q1-Q5 & \\
\hline \multirow[t]{2}{*}{ Alpha } & 0.648 & -0.430 & 1.078 & 0.293 & 0.048 & 0.245 & 0.833 \\
\hline & $(5.10)^{* * *}$ & $(-3.13)^{* * *}$ & $(6.09)^{* * *}$ & $(2.80)^{* * *}$ & $(0.29)$ & $(1.43)$ & $(3.46)^{* * *}$ \\
\hline \multirow[t]{2}{*}{$M K T R F$} & 1.036 & 1.097 & -0.061 & 0.979 & 1.212 & -0.234 & 0.172 \\
\hline & $(22.20)^{* * *}$ & $(26.27)^{* * *}$ & $(-0.91)$ & $(32.58)^{* * *}$ & $(31.39)^{* * *}$ & $(-5.71)^{* * *}$ & $(2.17)^{* *}$ \\
\hline \multirow[t]{2}{*}{$S M B$} & 0.406 & 0.872 & -0.467 & 0.557 & 0.894 & -0.337 & -0.130 \\
\hline & $(2.63) * * *$ & $(19.05)^{* * *}$ & $(-2.80) * * *$ & $(8.66)^{* * *}$ & $(15.85)^{* * *}$ & $(-5.72)^{* * *}$ & $(-0.81)$ \\
\hline \multirow[t]{2}{*}{$H M L$} & 0.149 & 0.315 & -0.166 & 0.219 & 0.203 & 0.016 & -0.182 \\
\hline & $(1.96)^{*}$ & $(3.99)^{* * *}$ & $(-1.40)$ & $(4.40)^{* * *}$ & $(3.50)^{* * *}$ & $(0.23)$ & $(-1.36)$ \\
\hline \multirow[t]{2}{*}{$U M D$} & -0.112 & -0.229 & 0.117 & -0.038 & -0.326 & 0.288 & -0.171 \\
\hline & $(-3.28)^{* * *}$ & $(-7.69)^{* * *}$ & $(2.46)^{* *}$ & $(-1.35)$ & $(-8.36)^{* * *}$ & $(5.20)^{* * *}$ & $(-2.26)^{* *}$ \\
\hline \multirow[t]{2}{*}{$E A R F$} & 0.162 & 0.149 & 0.013 & 0.139 & 0.122 & 0.018 & -0.004 \\
\hline & $(2.42)^{* *}$ & $(1.29)$ & $(0.10)$ & $(1.84)^{*}$ & (1.35) & $(0.20)$ & $(-0.03)$ \\
\hline
\end{tabular}

Notes: This table presents the results from calendar-time portfolio regressions using a Fama-French four-factor model augmented with an earnings announcement return factor $(E A R F)$. $M K T R F, S M B$, $H M L$, and $U M D$ are the Fama-French factors obtained through WRDS. Following Johnson et al. [2020], $E A R F$ is defined as the monthly difference between the value weighted return on a portfolio of firms expected to announce earnings and the value weighted return on a portfolio of firms not expected to announce earnings. In each of the 312 months in the sample, we rank observations into quintile portfolios based on the fitted and residual values obtained from the regressions in Table 4 for annual (Panel A) and quarterly (Panel B) forecast dispersion. The forecast dispersion variables are defined as in Appendix A. $t$-statistics are based on standard errors adjusted for autocorrelation using Newey and West [1987] and five lags. $* * *$, and $* * *$ represent statistical significance at the $0.10,0.05$, and 0.01 level, respectively. 
Table 6

Forecast dispersion and the predictability of earnings announcement returns

\begin{tabular}{|c|c|c|c|c|c|c|}
\hline & $B H A R_{t}^{[0,2]}$ & $B H A R_{t}^{[0,2]}$ & $B H A R_{t}^{[0,2]}$ & $B H A R_{t}^{[0,2]}$ & $B H A R_{t}^{[0,2]}$ & $B H A R_{t}^{[0,2]}$ \\
\hline \multicolumn{7}{|l|}{ Test variables: } \\
\hline$\overline{D i s p} A_{t}$ & $\begin{array}{c}-0.629 \\
(-5.54)^{* * *}\end{array}$ & $\begin{array}{c}-0.323 \\
(-3.77)^{* * *}\end{array}$ & $\begin{array}{l}0.121 \\
(1.16)\end{array}$ & & & \\
\hline $\operatorname{Disp}_{t}$ & & & & $\begin{array}{c}-0.560 \\
(-6.30)^{* * *}\end{array}$ & $\begin{array}{c}-0.310 \\
(-4.41)^{* * *}\end{array}$ & $\begin{array}{l}0.071 \\
(0.98)\end{array}$ \\
\hline \multicolumn{7}{|l|}{ Control variables: } \\
\hline Sizet $_{t}$ & $\begin{array}{c}0.281 \\
(1.89)^{*}\end{array}$ & $\begin{array}{l}-0.075 \\
(-0.47)\end{array}$ & $\begin{array}{c}-1.038 \\
(-6.99)^{* * *}\end{array}$ & $\begin{array}{c}0.314 \\
(1.97)^{*}\end{array}$ & $\begin{array}{l}-0.080 \\
(-0.49)\end{array}$ & $\begin{array}{c}-1.044 \\
(-7.02)^{* * *}\end{array}$ \\
\hline$B t M_{t}$ & $\begin{array}{c}0.643 \\
(6.30)^{* * *}\end{array}$ & $\begin{array}{c}0.345 \\
(4.47)^{* * *}\end{array}$ & $\begin{array}{c}0.401 \\
(4.70)^{* * *}\end{array}$ & $\begin{array}{c}0.648 \\
(6.35)^{* * *}\end{array}$ & $\begin{array}{c}0.338 \\
(4.54)^{* * *}\end{array}$ & $\begin{array}{c}0.409 \\
(4.84)^{* * *}\end{array}$ \\
\hline$A R_{t}^{[-1]}$ & $\begin{array}{c}-1.419 \\
(-10.56)^{* * *}\end{array}$ & $\begin{array}{c}-1.434 \\
(-10.70)^{* * *}\end{array}$ & $\begin{array}{c}-1.843 \\
(-13.52)^{* * *}\end{array}$ & $\begin{array}{c}-1.416 \\
(-10.51)^{* * *}\end{array}$ & $\begin{array}{c}-1.433 \\
(-10.68)^{* * *}\end{array}$ & $\begin{array}{c}-1.842 \\
(-13.51)^{* * *}\end{array}$ \\
\hline$A R_{t}^{[-2]}$ & $\begin{array}{c}-0.839 \\
(-6.14)^{* * *}\end{array}$ & $\begin{array}{c}-0.861 \\
(-6.25)^{* * *}\end{array}$ & $\begin{array}{c}-1.129 \\
(-8.31)^{* * *}\end{array}$ & $\begin{array}{c}-0.836 \\
(-6.11)^{* * *}\end{array}$ & $\begin{array}{c}-0.860 \\
(-6.23)^{* * *}\end{array}$ & $\begin{array}{c}-1.128 \\
(-8.30)^{* * *}\end{array}$ \\
\hline$A R_{t}^{[-3]}$ & $\begin{array}{c}-0.484 \\
(-3.94)^{* * *}\end{array}$ & $\begin{array}{c}-0.504 \\
(-4.03)^{* * *}\end{array}$ & $\begin{array}{c}-0.734 \\
(-5.65)^{* * *}\end{array}$ & $\begin{array}{c}-0.478 \\
(-3.87)^{* * *}\end{array}$ & $\begin{array}{c}-0.500 \\
(-3.99)^{* * *}\end{array}$ & $\begin{array}{c}-0.731 \\
(-5.62)^{* * *}\end{array}$ \\
\hline$A R_{t}^{[-4]}$ & $\begin{array}{c}-0.449 \\
(-3.86)^{* * *}\end{array}$ & $\begin{array}{c}-0.473 \\
(-4.03)^{* * *}\end{array}$ & $\begin{array}{c}-0.662 \\
(-5.36)^{* * *}\end{array}$ & $\begin{array}{c}-0.447 \\
(-3.82)^{* * *}\end{array}$ & $\begin{array}{c}-0.473 \\
(-4.01)^{* * *}\end{array}$ & $\begin{array}{c}-0.661 \\
(-5.34)^{* * *}\end{array}$ \\
\hline$A R_{t}^{[-5]}$ & $\begin{array}{c}-0.282 \\
(-2.70)^{* * *}\end{array}$ & $\begin{array}{c}-0.300 \\
(-2.85)^{* * *}\end{array}$ & $\begin{array}{c}-0.481 \\
(-4.54)^{* * *}\end{array}$ & $\begin{array}{c}-0.276 \\
(-2.65)^{* * *}\end{array}$ & $\begin{array}{c}-0.296 \\
(-2.82)^{* * *}\end{array}$ & $\begin{array}{c}-0.478 \\
(-4.52)^{* * *}\end{array}$ \\
\hline$B H A R_{t}^{[-10,-6]}$ & $\begin{array}{c}-0.353 \\
(-3.22)^{* * *}\end{array}$ & $\begin{array}{c}-0.382 \\
(-3.47)^{* * *}\end{array}$ & $\begin{array}{c}-0.730 \\
(-6.62)^{* * *}\end{array}$ & $\begin{array}{c}-0.350 \\
(-3.23) * * *\end{array}$ & $\begin{array}{c}-0.382 \\
(-3.51)^{* * *}\end{array}$ & $\begin{array}{c}-0.730 \\
(-6.68) * * *\end{array}$ \\
\hline Lev $_{t}$ & $\begin{array}{l}-0.138 \\
(-1.56)\end{array}$ & $\begin{array}{c}-0.257 \\
(-2.63)^{* * *}\end{array}$ & $\begin{array}{l}0.012 \\
(0.11)\end{array}$ & $\begin{array}{l}-0.126 \\
(-1.44)\end{array}$ & $\begin{array}{c}-0.257 \\
(-2.65)^{* * *}\end{array}$ & $\begin{array}{l}0.006 \\
(0.05)\end{array}$ \\
\hline$A g e_{t}$ & $\begin{array}{l}0.182 \\
(1.34)\end{array}$ & $\begin{array}{l}-0.015 \\
(-0.17)\end{array}$ & $\begin{array}{l}0.138 \\
(1.20)\end{array}$ & $\begin{array}{l}0.198 \\
(1.44)\end{array}$ & $\begin{array}{l}-0.014 \\
(-0.16)\end{array}$ & $\begin{array}{l}0.128 \\
(1.10)\end{array}$ \\
\hline Analysts $_{t}$ & $\begin{array}{l}-0.031 \\
(-0.27)\end{array}$ & $\begin{array}{c}0.198 \\
(1.79)^{*}\end{array}$ & $\begin{array}{c}0.342 \\
(2.49)^{* *}\end{array}$ & $\begin{array}{l}-0.050 \\
(-0.42)\end{array}$ & $\begin{array}{l}0.196 \\
(1.76)^{*}\end{array}$ & $\begin{array}{c}0.347 \\
(2.52)^{* *}\end{array}$ \\
\hline Inst $_{t}$ & $\begin{array}{c}0.509 \\
(4.27)^{* * *}\end{array}$ & $\begin{array}{c}0.621 \\
(4.59)^{* * *}\end{array}$ & $\begin{array}{c}0.440 \\
(3.27)^{* * *}\end{array}$ & $\begin{array}{c}0.529 \\
(4.41)^{* * *}\end{array}$ & $\begin{array}{c}0.636 \\
(4.74)^{* * *}\end{array}$ & $\begin{array}{c}0.439 \\
(3.28)^{* * *}\end{array}$ \\
\hline Retvol $_{t}$ & & $\begin{array}{c}-0.409 \\
(-3.44)^{* * *}\end{array}$ & $\begin{array}{l}-0.075 \\
(-0.69)\end{array}$ & & $\begin{array}{c}-0.415 \\
(-3.27)^{* * *}\end{array}$ & $\begin{array}{l}-0.052 \\
(-0.45)\end{array}$ \\
\hline Evol $_{t}$ & & $\begin{array}{c}-0.414 \\
(-3.07)^{* * *}\end{array}$ & $\begin{array}{c}-0.702 \\
(-4.80)^{* * *}\end{array}$ & & $\begin{array}{c}-0.433 \\
(-3.16)^{* * *}\end{array}$ & $\begin{array}{c}-0.693 \\
(-4.80)^{* * *}\end{array}$ \\
\hline Turn $_{t}$ & & $\begin{array}{c}-0.391 \\
(-3.43)^{* * *}\end{array}$ & $\begin{array}{c}-0.703 \\
(-5.99)^{* * *}\end{array}$ & & $\begin{array}{c}-0.404 \\
(-3.56)^{* * *}\end{array}$ & $\begin{array}{c}-0.709 \\
(-6.01)^{* * *}\end{array}$ \\
\hline Surprise $_{t}$ & & & $\begin{array}{c}7.613 \\
(17.70)^{* * *}\end{array}$ & & & $\begin{array}{c}7.606 \\
(17.75)^{* * *}\end{array}$ \\
\hline $\mathrm{n}$ & 290,774 & 290,774 & 290,774 & 290,774 & 290,774 & 290,774 \\
\hline n (quarters) & 104 & 104 & 104 & 104 & 104 & 104 \\
\hline Average adj. $R^{2}$ & 0.012 & 0.014 & 0.087 & 0.011 & 0.014 & 0.087 \\
\hline
\end{tabular}

Notes: Panel A presents average coefficient estimates obtained from quarterly cross-sectional regressions of earnings announcement returns on forecast dispersion and control variables. Average coefficients are multiplied by 100 for presentation purposes. All independent variables are transformed into quarterly decile ranks, scaled between -0.5 and 0.5. See Appendix A for details on the variable definitions. $t$-statistics are based on time series averages and standard errors adjusted for autocorrelation using Newey and West [1987] and five lags. ${ }^{*}, * *$, and $* * *$ represent statistical significance at the $0.10,0.05$, and 0.01 level, respectively. 
Table 7

Relation between forecast dispersion and meeting earnings expectations

Panel A: Forecast dispersion and firms' ex-post propensity to meet or beat earnings expectations

\begin{tabular}{|c|c|c|c|c|}
\hline & Meet $_{t}$ & $\begin{array}{c}\text { Average } \\
\text { marg. effect }\end{array}$ & Meet $_{t}$ & $\begin{array}{c}\text { Average } \\
\text { marg. effect }\end{array}$ \\
\hline \multicolumn{5}{|l|}{ Test variables: } \\
\hline $\operatorname{Disp}_{t}$ & $\begin{array}{c}-1.052 \\
(-36.39)^{* * *}\end{array}$ & -0.223 & & \\
\hline$D_{i s p} Q_{t}$ & & & $\begin{array}{c}-1.084 \\
(-38.26)^{* * *}\end{array}$ & -0.229 \\
\hline \multicolumn{5}{|l|}{ Control variables: } \\
\hline Size $_{t}$ & $\begin{array}{c}0.393 \\
(7.62)^{* * *}\end{array}$ & 0.083 & $\begin{array}{c}0.370 \\
(7.38)^{* * *}\end{array}$ & 0.078 \\
\hline$B t M_{t}$ & $\begin{array}{c}-0.346 \\
(-7.20)^{* * *}\end{array}$ & -0.073 & $\begin{array}{c}-0.351 \\
(-7.27)^{* * *}\end{array}$ & -0.074 \\
\hline$B H A R_{t}^{[-60,-1]}$ & $\begin{array}{c}0.855 \\
(9.78)^{* * *}\end{array}$ & 0.182 & $\begin{array}{c}0.860 \\
(9.82)^{* * *}\end{array}$ & 0.182 \\
\hline $\operatorname{Lev}_{t}$ & $\begin{array}{c}-0.448 \\
(-13.24)^{* * *}\end{array}$ & -0.095 & $\begin{array}{c}-0.415 \\
(-12.14)^{* * *}\end{array}$ & -0.088 \\
\hline $\mathrm{Age}_{t}$ & $\begin{array}{c}-0.291 \\
(-4.44)^{* * *}\end{array}$ & -0.061 & $\begin{array}{c}-0.275 \\
(-4.02)^{* * *}\end{array}$ & -0.058 \\
\hline Analysts $_{t}$ & $\begin{array}{c}0.224 \\
(2.89)^{* * *}\end{array}$ & 0.047 & $\begin{array}{c}0.228 \\
(3.34)^{* * *}\end{array}$ & 0.048 \\
\hline Inst $_{t}$ & $\begin{array}{c}0.246 \\
(7.62)^{* * *}\end{array}$ & 0.052 & $\begin{array}{c}0.274 \\
(8.52)^{* * *}\end{array}$ & 0.057 \\
\hline Retvol $_{t}$ & $\begin{array}{c}-0.167 \\
(-3.12)^{* * *}\end{array}$ & -0.036 & $\begin{array}{c}-0.200 \\
(-3.70)^{* * *}\end{array}$ & -0.042 \\
\hline Evol $_{t}$ & $\begin{array}{c}0.092 \\
(2.58)^{* *}\end{array}$ & 0.019 & $\begin{array}{c}0.076 \\
(2.51)^{* *}\end{array}$ & 0.016 \\
\hline Turn $_{t}$ & $\begin{array}{l}0.035 \\
(0.83)\end{array}$ & 0.007 & $\begin{array}{l}0.019 \\
(0.43)\end{array}$ & 0.004 \\
\hline $\mathrm{n}$ & 290,774 & & 290,774 & \\
\hline n (quarters) & 104 & & 104 & \\
\hline Average Pseudo $R^{2}$ & 0.067 & & 0.069 & \\
\hline
\end{tabular}

Panel B: Within-quarter effect of public earnings guidance on forecast dispersion

\begin{tabular}{lcc}
\hline & Meet $_{t}$ & $\ln \left(\right.$ Disp $\left._{t}\right)$ \\
\hline Guide $_{t}$ & -0.055 & -0.181 \\
& $(-6.34)^{* * *}$ & $(-10.15)^{* * *}$ \\
Post $_{t}$ & 0.150 & -0.205 \\
Guide $_{t} \times$ Post $_{t}$ & $(27.27)^{* * *}$ & $(-15.74)^{* * *}$ \\
& 0.074 & -0.082 \\
\hline Firm fixed effects & $(17.94)^{* * *}$ & $(-4.81)^{* * *}$ \\
Year-quarter fixed effects & Included & Included \\
n & Included & Included \\
n (firm-quarters) & 314,646 & 314,646 \\
Adj. $R^{2}$ & 157,323 & 157,323 \\
\hline
\end{tabular}


Notes: Panel A presents average coefficient estimates obtained from quarterly logit regressions of indicator variable Meet $_{t}$ on forecast dispersion and control variables. All independent variables are transformed into quarterly decile ranks, scaled between -0.5 and 0.5. Marginal effects are computed based on the average of the quarterly estimates and capture the difference in the conditional probability that Meet $_{t}=1$ between firms in the highest and lowest decile of the independent variable of interest, while holding all other variables constant at their means for the quarter. Panel B presents difference-in-difference OLS regressions of the within-quarter effect of public earnings guidance on the probability that firms meet or beat the consensus forecast and forecast dispersion, respectively. For each firm-quarter in our sample, we create two data points and define the dependent variables based on the consensus forecast measured either 120 days or 1 day before the earnings announcement. Post $t_{t}$ is an indicator variable set equal to 0 when the dependent variable is measured 120 days before the earnings announcement (i.e., pre-guidance), and set equal to 1 when the dependent variable is measured 1 day before the earnings announcement (i.e., post-guidance). We restrict these tests to firms that provide public earnings guidance at least once in the sample. See Appendix $\mathrm{A}$ for details on the variable definitions. In Panels A and B, $t$-statistics are based on time series averages and standard errors adjusted for autocorrelation using Newey and West [1987] and five lags. *, **, and *** represent statistical significance at the $0.10,0.05$, and 0.01 level, respectively. 